\title{
DESIGN AND SYNTHESIS OF PHTHALAZINE BASED DERIVATIVES AS POTENTIAL ANTICANCER AGENTS BY
}

\author{
SalwaElmeligie $^{1}$, Asmaa M. Aboul-Magd ${ }^{2}$, Deena S. Lasheen ${ }^{3}$, Khaled A. M.Abouzid ${ }^{3}$ \\ FROM \\ ${ }^{1}$ Pharmaceutical Organic Chemistry Department, Faculty of Pharmacy, Cairo \\ University, Cairo, Egypt \\ ${ }^{2}$ Pharmaceutical Chemistry Department, Faculty of Pharmacy, \\ Modern University for Technology\& Information , Cairo, Egypt \\ ${ }^{3}$ Pharmaceutical Chemistry Department, Faculty of Pharmacy, Ain Shams University, \\ Cairo, Egypt
}

\begin{abstract}
In an attempt to develop novel targeted anticancer agents, a series of novel substituted phthalazine derivatives has been designed and synthesized as inhibitors of vascular endothelial growth factor receptor (VEGFR) kinase enzyme in accordance to SAR studies of known VEGFR inhibitors. The designed compounds incorporated a biarylamide or biarylurea tail linked to a phthalazine scaffold via an amino or ether linkage or else incorporated an N-substituted piperazine motif at position 1 of the phthalazine core. The prepared compounds were evaluated for their enzymatic inhibition of VEGFR-2 kinase. Furthermore, three of the phthalazines bearing a biarylurea $(\mathbf{6 b}, \mathbf{6 e} \boldsymbol{\& 7 \mathbf { b } )}$ ) exhibited excellent broad spectrum cell growth inhibition against NCI full 60 cell panel with GI $_{50}$ values between $0.15-5 \mu \mathrm{M}$. In addition, docking studies were performed through docking of the investigated compounds into VEGFR-2 binding site in order to gain further insight into their binding affinities and binding interactions with the VEGFR-2 kinase.
\end{abstract}

Key words: Substituted phthalazines, Cytotoxic activity, Kinase inhibitors, VEGFR-2

\section{Introduction}

Cancer is one ofthe major leading causes of death worldwide(ShulanZhang, 2010). It is estimated that cancer accounts for one of every five deaths. Moreover, it is estimated that the annual number of deaths due to cancers will increase from 7.6 million in 2008 to 13 million in 2030(Ales Imramovský 2013). Despite improved imaging and molecular diagnostic techniques, and advances in prevention and chemotherapeutic management, the disease still affects many millions of patients worldwide (Nakhjiri et al., 2012). Apart from surgical treatment and irradiation techniques, chemotherapy still remains an important option for cancer therapy.

It was suggested that the vast catalog of cancer cell genotypes are manifestation of six essential alterations in cell physiology that collectively dictate malignant growth; self-sufficiency in growth signals, insensitivity to growth-inhibitory (antigrowth) signals, evasion of programmed cell death (apoptosis), limitless replicative potential, sustained angiogenesis, and tissue invasion and metastasis. Each of these physiologic changes acquired during tumor development can represent a successful breaching of an 
anticancer defense mechanism hardwired into cells and tissues(Hanahan\& Weinberg, 2011).

Vascular endothelial growth factor (VEGF) has been considered to play a major role in angiogenesis, the process of sprouting of new blood vessel formations from preexisting ones. This process begins with the dilatation of pre-existing capillaries and venules, followed by an increase of vascular permeability. Endothelial cells, which constitute the vessels, become activated, detach, migrate, and proliferate to form new sprouts(Zhang et al., 2009, Qun Zhao, 2010,Musumeci et al., 2012). Normal angiogenesis occurs during ovulation, wound healing, and reproduction. Physiological angiogenesis is tightly controlled by a complex balance among endogenous proangiogenic and antiangiogenic factors(Clarke\& Hurwitz, 2013). Aberrant angiogenesis is present in a wide range of diseases including retinopathies, arthritis, endometriosis, atherosclerosis, and cancer (Potente, 2011).

One approach for inhibiting or reducing angiogenesis involves retarding, modulating or inhibiting the effects of VEGF binding at the VEGF receptor 2 (VEGFR2); also known as the kinase insert domain receptor or (KDR), a receptor tyrosine kinase expressed on vascular endothelial cells (Francesca Musumeci, 2012).

Binding of VEGFs to their specific VEGFRs induces receptor dimerization, resulting in modification in the intracellular domain conformation. These conformational changes lead to the exposure of an ATP-binding site, followed by ATP binding and auto- or transphosphorylation on specific tyrosine residues on the receptor dimmers (Holmes, 2007) and on downstream signal transduction proteins (Koch, 2011). This mechanism leads to the initiation of a typical receptor signal transduction cascade, which activates several downstream enzymatic pathways, including p38MAPK, Raf/ MEK/ERK, and PI3K/PKB pathways(Tomao et al., 2014). Thus inhibition of VEGFR kinase has been considered as an attractive target in developing novel anticancer therapeutics.

Multiple reports have detailed several small-molecule inhibitors of VEGFR-2 acting by binding to the ATP binding site in the intracellular kinase domain resulting in diminished VEGF signal transduction, these inhibitors may be broadly categorized into two main types; type I inhibitors represent ATP competitors that generally bind in or around the catalytic site of the kinase in its active conformation, in the region originally occupied by the adenine moiety of ATP (Zhang et al., 2009). On the other hand, type II inhibitors stabilize the inactive conformation of the enzyme derived upon the movement of the DFG motif, hence, they exploit new interactions with the lipophilic pocket revealed in this new rearrangement(Jabbour et al., 2013).

In the past few years, a number of VEGFR-2 inhibitors have proven clinical success. Among these, Vatalanib (PTK-787) (I) (Fig. 1), the 1,4-disubstituted phthalazine inhibitor, which is in Phase III clinical trials for metastatic colorectal cancer (Scott et al., 2007).

The biarylurea based inhibitor sorafenib (II)(Fig. 1), has been approved for treatment of advanced renal cell carcinoma (Brian B. Hasinoff 2010). Interestingly, sorafenib is not a specific inhibitor of its primary target enzyme, but also displays potent inhibitory activity for the kinase domain of the B-raf and platelet derived growth factor receptor beta (PDGFRB), which may also contribute to its antiangiogenic effects. The 
promising clinical efficacy of sorafenib may be attributed to the combination of VEGFR1-2, PDGFR- $\beta$, and B-raf (Ott et al., 2010).

Interest in developing novel biarylurea-based VEGFR-2 inhibitors has been increasingly highlighted with the clinical success of other sorafenib analogues as regorafenib(III)and linifanib (IV)(Chuma et al., 2014). Also, the quinazoline derivative (V)was reported as a potent inhibitor of VEGFR-2 in addition to being efficacious in HepG2 human tumor xenograft model in BALB/c-nu mice(Yu et al., 2012).

Moreover, AAL993 (VI)is known as a hybrid-design type II inhibitor derived from the type I inhibitor vatalanib. It is considered as a potent inhibitor of VEGFR family that was identified after main optimization of an anthranilamide series(Blanc et al., 2013).

From another point of view, the piperazinyl moiety, the small rigid heterocyclic motif, has been successfully incorporated in several potent kinase inhibitors(L. Garuti, 2009,Shallal\& Russu, 2011,Rice et al., 2012,Zhang et al., 2010,Pollard\& Mortimore, 2009). The aryl piperazine based derivative (VII) (Fig. 1), has been reported to exhibit potent single digit nanomolar inhibitory activity on specific kinases(Musumeci\& Radi\& Brullo\& Schenone, 2012,Abouzid et al., 2012).In a recent disclosure, the SAR and synthesis of pyrazolopyrimidines as potent and selective AKT1 and p70S6K kinase inhibitors, of which compound (VIII) also demonstrated potent in vivo tumor growth inhibition(Rice\& Kim\& Bussenius\& Anand\& Blazey\& Bowles\& Canne-Bannen\& Chan\& Chen\& Co\& Costanzo\& DeFina\& Dubenko\& Engst\& Franzini\& Huang\& Jammalamadaka\& Khoury\& Klein\& Laird\& Le\& Mac\& Matthews\& Markby\& Miller\& Nuss\& Parks\& Tsang\& Tsuhako\& Wang\& Xu, 2012). 
<smiles>Clc1ccc(Nc2nnc(Cc3ccncc3)c3ccccc23)cc1</smiles>

Vatalanib (PTK-787) (I)

$I_{50}($ VEGFR2 $)=43 \mathrm{nM}$<smiles>CNC(=O)c1cc(Oc2ccc(NC(=O)Nc3ccc(Cl)c(C(F)(F)F)c3)cc2)ccn1</smiles>

Sorafenib (II)

$\mathrm{IC}_{50}(\mathrm{VEGFR2})=7-10 \mathrm{nM}$ $\mathrm{IC}_{50}(\mathrm{c}-\mathrm{KIT})=7-10 \mathrm{nM}$

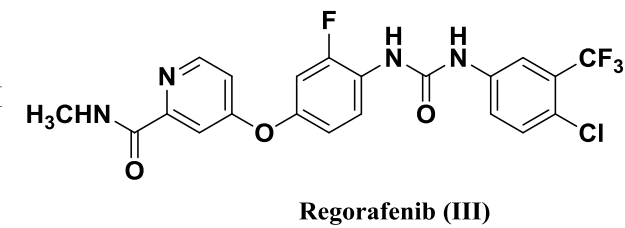

$\mathrm{IC}_{50}($ VEGFR2 $)=4.2 \mathrm{nM}$

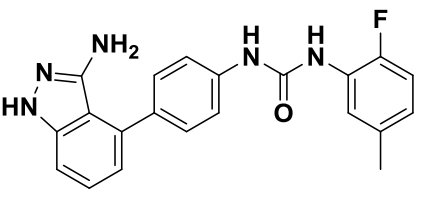

Linifanib (IV)

IC $_{50}($ VEGFR2 $)=4 \mathrm{nM}$

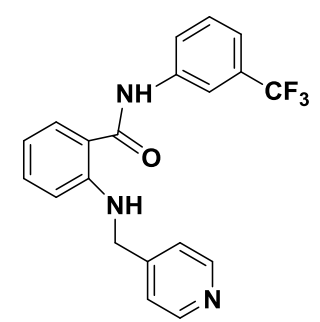

AAL993 (VI)

$I_{50}($ VEGFR2 $)=23 \mathrm{nM}$

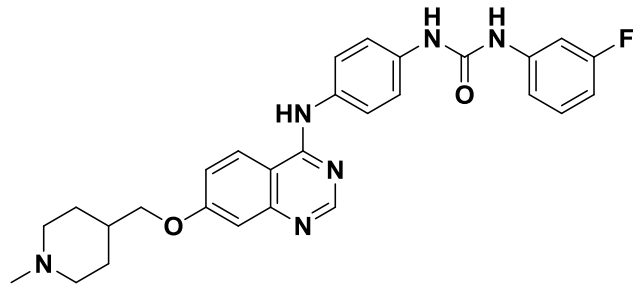

(V); $\mathrm{IC}_{50}(\mathrm{VEGFR} 2)=5.5 \mathrm{nM}$

Fig. 1: Structures of some potent tyrosine kinase inhibitors.

\section{Rationale and design}

Based on the above findings, three series of phthalazine-based derivatives linked to abiarylamide or biarylurea tail to position 1 of the phthalazine core via an amino or ether linkage ehave been designed and synthesized as VEGFR-2 kinase inhibitors. In addition, different substitution pattern have been introduced to the terminal aromatic ring aiming to better occupy to the hydrophobic pocket revealed by the kinase in its DFG-out conformation, (Fig 2).The design of these series was based on the study of structure activity relationships as well as common pharmacophoric features shared by several type II VEGFR inhibitors which involve; a flat heteroaromatic ring system that occupies the ATP binding region of the kinase, hydrogen bond donor-acceptor pair represented by the urea or amide moieties which usually form hydrogen bonds with Glu 885 and Asp 1046 residues, in addition to a substituted terminal aryl moiety to occupy the hydrophobic pocket revealed by the movement of the DFG motif of the kinase in its 
inactive conformation (D.M. Sammond, 2005). Furthermore, a fourth series of substituted piperazine based derivatives was also designed to target the human kinome via linking the two major fragments; the phthalazine core, recognized as a kinase privileged fragment, to the piperazine moiety aiming to offer morerigidity and to facilitate deriving spatial-activity relationships. Thus, phthalazine based derivatives bearing substituted piperazinyl moieties were also designed (Shallal\& Russu, 2011).

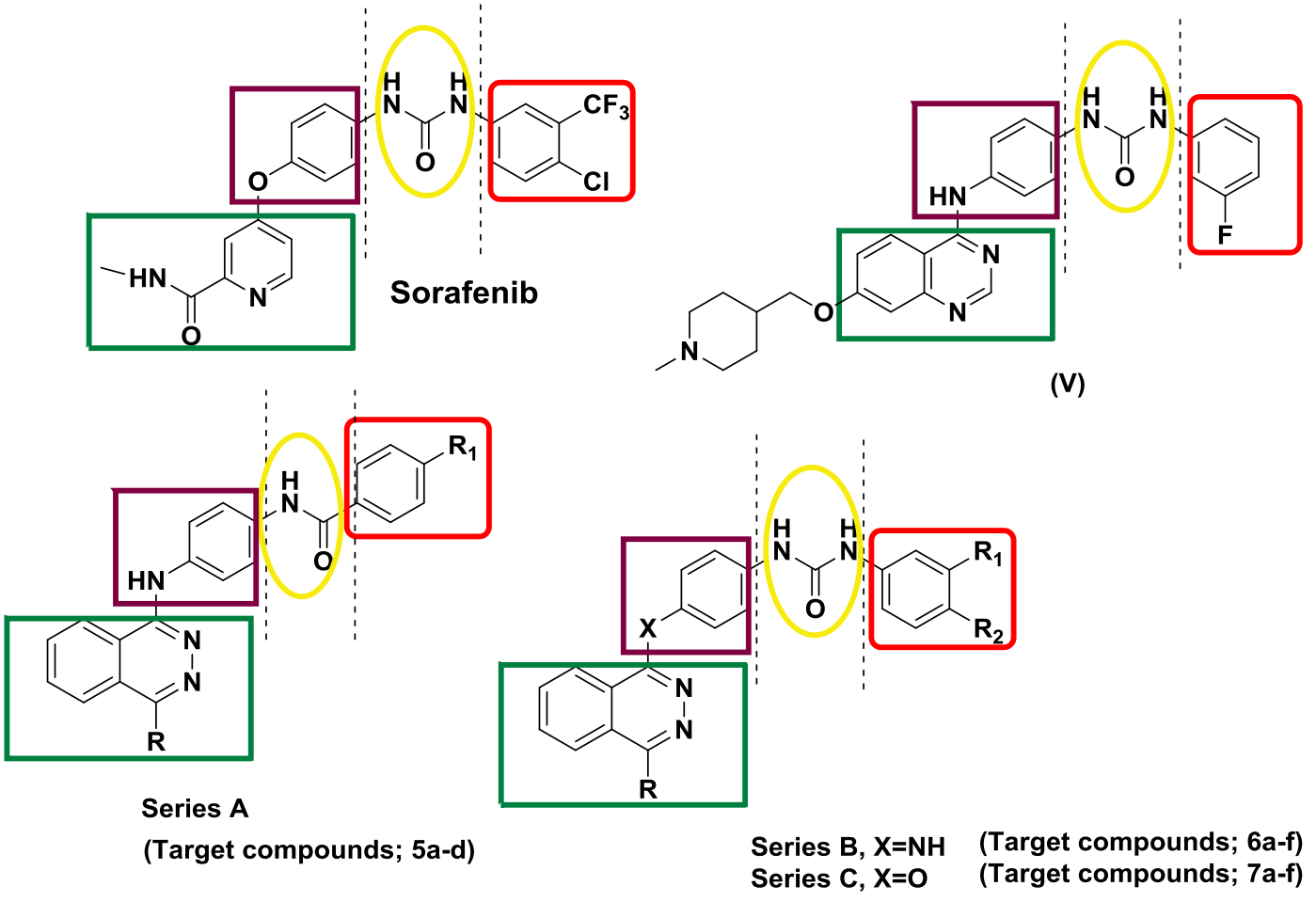

Fig. 2: Strategy for the design of the target compounds 5a-d, 6a-f and 7a-f.

\section{Results and discussion}

\subsection{Chemistry}

The pathways adopted for the synthesis of the new substituted phthalazine derivatives are depicted in $\operatorname{Schemes(1a,b).~The~key~intermediates~1-aryl-3-(4-~}$ hydroxyphenyl)urea (1a-c), were prepared following the literature methods as illustrated in Scheme 1a(Stout et al., 1985). On the other hand cyclization of the respective ortho substituted benzoic acid derivative with hydrazine hydrate afforded the corresponding phthalazinones $(\mathbf{2} \mathbf{a}, \mathbf{b})$.Chlorination of $\mathbf{2 a}, \mathbf{b}$ with phosphorous oxychloride afforded the corresponding1-chlorophthalazines(3a,b) which were used to prepare the target series of 1 -substituted phthalazines via reaction with various nucleophiles. Thus, the reaction of 3a,b with p-phenylenediamine in butanol afforded the $\mathrm{N}^{1}$-(phthalazin-1-yl)benzene-1,4diamines $(\mathbf{4 a}, \mathbf{b})$. The latter compounds $\mathbf{( 4 a , b )}$ were further reacted with the respective benzoyl chloride in acetonitrile, in presence of triethylamine to afford the target phthalazines bearing the biarylamide tail(5a-d). Moreover, the reaction of $(\mathbf{4 a}, \mathbf{b})$ with different isocyanates in DMF yielded the biarylurea(6a-f). On the other hand, 1-Aryl-3(4-(4-substituted phthalazin-1-yloxy)phenyl)urea(7a-f) were obtained via reacting the respective 1-chlorophthalazines (3a,b)with the appropriate intermediates (1a-c) in refluxing acetonitrile. Finally, refluxing the1-chlorophthalazines(3a,b) with the 
appropriate piperazine derivative in ethanol yielded the target phthalazines bearing the substituted piperazinyl tail (8a-j)in a good yield (Scheme 1b).<smiles>Nc1ccc(O)cc1</smiles><smiles>[R2]c1ccc(N=C=O)cc1[R]</smiles><smiles>[R]c1ccc(NC(=O)Nc2ccc(O)cc2)cc1[R2]</smiles>

1a: $R_{1}=H, R_{2}=H$

1a-c

1b: $R_{1}=H, R_{2}=C l$

1c: $R_{1}=C_{3}, R_{2}=C l$

Scheme 1a: Reagents and conditions: i) dioxane, rt, $1 \mathrm{~h}$. 
<smiles>[R]C(=O)c1ccccc1C(=O)O</smiles><smiles>CC(C)C</smiles>

$\mathrm{R}=\mathrm{H}, \mathrm{CH}_{3}$<smiles>[R]c1nnc(Nc2ccc(N)cc2)c2ccccc12</smiles>

4a,b

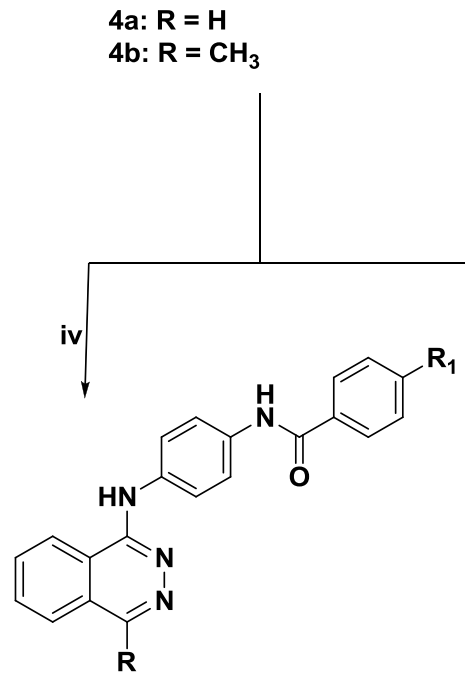

5a-d<smiles>[R]c1nnc(Cl)c2ccccc12</smiles>

3a: $\mathbf{R}=\mathbf{H}$

3b: $\mathbf{R}=\mathrm{CH}_{3}$

$\mathbf{2 a , b}$<smiles>[R2]c1ccc(NC(=O)Nc2ccc(Oc3nnc([R])c4ccccc34)cc2)cc1[R2]</smiles>

7a: $\mathbf{R}=\mathbf{R}_{\mathbf{1}}=\mathbf{R}_{\mathbf{2}}=\mathbf{H}$

7b: $R=R_{1}=H, R_{2}=C l$

7c: $R=H, R_{1}=C F_{3}, R_{2}=C l$

$7 \mathrm{~d}: \mathbf{R}=\mathbf{C H}_{\mathbf{3}}, \mathbf{R}_{\mathbf{1}}=\mathbf{R}_{\mathbf{2}}=\mathbf{H}$

7e: $\mathbf{R}=\mathrm{CH}_{\mathbf{3}}, \mathrm{R}_{\mathbf{1}}=\mathrm{H}, \mathrm{R}_{\mathbf{2}}=\mathrm{Cl}$

7f: $\mathbf{R}=\mathrm{CH}_{3}, \mathrm{R}_{\mathbf{1}}=\mathrm{CF}_{3}, \mathrm{R}_{\mathbf{2}}=\mathrm{Cl}$

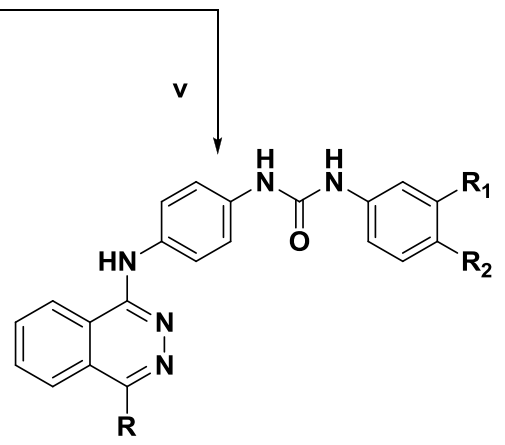

6a-f

6a: $R=R_{1}=R_{2}=H$

6b: $R=R_{1}=H, R_{2}=C l$

6c: $R=H, R_{1}=C_{3}, R_{2}=C l$

6d: $\mathbf{R}=\mathbf{C H}_{\mathbf{3}}, \mathbf{R}_{\mathbf{1}}=\mathbf{R}_{\mathbf{2}}=\mathbf{H}$

6e: $R=C_{3}, R_{1}=H, R_{2}=C l$

6f: $R=C_{3}, R_{1}=C_{3}, R_{2}=C l$

Scheme 1b: Reagents and conditions: i) $\mathrm{NH}_{2} \mathrm{NH}_{2} 99 \%$, propanol, w.b., $2 \mathrm{~h}$ ii) $\mathrm{POCl}_{3}$, reflux $70{ }^{\circ} \mathrm{C}, 2 \mathrm{~h}$ iii) p-phenylenediamine, butanol, w.b., 1h, iv) benzoyl chlorides, acetonitile, triethylamine v)phenylisocyanates, DMF, reflux, 8h, vi) 1a-c, $\mathrm{Cs}_{2} \mathrm{CO}_{3}$, acetonitrile, reflux, $6 \mathrm{~h}$, vii) piperazines, $\mathrm{K}_{2} \mathrm{CO}_{3}$, $\mathrm{KI}$, ethanol, reflux, $3 \mathrm{~h}$. 


\subsection{Biological Evaluation}

\subsubsection{In vitro anticancer screening at full NCI 60 cell panel}

Aiming to assess the general antitumor activity of the synthesized phthalazines, the structures of the final compounds were submitted to National Cancer Institute "NCI" (www.dtp.nci. nih.gov), Bethesda, Maryland, USA. In vitro NCI anticancer screening is a two-stage process, beginning with the evaluation of the selected compounds against the full NCI 60 cell lines panel representing leukemia, Non-Small Cell Lung Cancer, melanoma, colon cancer, CNS cancer, breast cancer, ovarian cancer, renal cancer and prostate cancer at a single dose of $10 \mu \mathrm{M}$. NCI selection is based on degree of structure variation and application of computer modeling techniques to prioritize compounds based on their ability to add diversity to the NCI small molecule compound collection.

Twelve of the submitted phthalazines $(\mathbf{5 b}, \mathbf{5 d}, \mathbf{6 b}, \mathbf{6 e}, \mathbf{7 b}, 7 \mathrm{e}, 8 \mathrm{a}, 8 \mathrm{~d}, \mathbf{8 f}, \mathbf{8 g}, 8 \mathrm{~h}$ and 8i) were selected under the NCI drug discovery program for screening against the full NCI 60 cell panel at single dose $10 \mu \mathrm{M}$. Among the investigated twelve compounds, three compounds $(\mathbf{6 b}, \mathbf{6 e}$ and $\mathbf{7 b})$ were selected by NCI for further screening at 5-log dose molar range due to their selective prominent cell growth inhibition on leukemia, renal and breast cell lines.

\subsubsection{Primary in vitro antineoplastic single dose assay.}

Primary in vitro single dose anticancer assay was performed in full NCI 60 cell panel. Results for each compound were reported as a mean graph of the percent growth of the treated cells compared to the untreated control cells. Three of the investigated substituted phthalazine-based derivatives showed a distinctive pattern of sensitivity against different NCI cell lines(Table 1). The biarylurea based derivative (6b) linked to the phthalazine core via an NH linker exhibited remarkable broad spectrum cell growth inhibition above $90 \%$ against various cell lines including leukemia, non-small cell lung cancer, melanoma, prostate cancer and breast cancer cell lines. In addition, its analogue (6e) having a methyl substituent at 4-position of phthalazine scaffold exhibited even more potent and broad spectrum inhibition above 100\%against a wide variety of NCI cell lines including leukemia, colon cancer, CNS cancer, melanoma, renal cancer and breast cancer cell lines. Interestingly, it showed highly potent inhibition above $100 \%$ against most of the tested leukemia and melanoma cell lines. Furthermore, the biarylurea analogue (7b) linked to the phthalazine nucleus via an ether linkage also showed excellent mean growth inhibition of $106.99 \%$ due to its broad spectrum inhibition against most of the tested NCI cell lines representing all the nine tumor subpanels specially those of leukemia, colon, melanoma and breast cancer cell lines. On the contrary, compounds $\mathbf{8 a}, \mathbf{8 d}, \mathbf{8 f}, \mathbf{8 g}, \mathbf{8 h}, \mathbf{8 i}$ have not shown any significant cell line growth inhibition under the same test conditions.

Table 1: In vitro NCI 60 cell line anticancer screening results of compounds $(\mathbf{5 b}, \mathbf{5 d}$, 6b, 6e, 7b, 7e, 8a, 8d, 8f, 8g, 8h, 8i) at single dose of $10 \mu \mathrm{M}$ presented as percent cell growth promotion. 


\begin{tabular}{|c|c|c|c|c|c|c|c|c|c|c|c|c|}
\hline $\begin{array}{c}\text { Panel/Cell } \\
\text { Line }\end{array}$ & $5 \mathbf{b}$ & $5 d$ & $6 \mathbf{b}$ & $6 e$ & $7 \mathrm{~b}$ & $7 e$ & $8 \mathbf{a}$ & $8 d$ & $8 f$ & $8 g$ & $8 \mathrm{~h}$ & $8 \mathbf{i}$ \\
\hline \multicolumn{13}{|l|}{ Leukemia } \\
\hline CCRF-CEM & 103.12 & 90.95 & 13.13 & 11.02 & 8.70 & 40.21 & 96.87 & 102.23 & 102.72 & 103.32 & 99.65 & 102.09 \\
\hline HL-60(TB) & 102.89 & 102.77 & 18.13 & -34.81 & 3.65 & 80.06 & 107.55 & 96.63 & 113.97 & 103.11 & 110.23 & 108.28 \\
\hline K-562 & 102.10 & 100.79 & 9.49 & -16.67 & 5.58 & 61.10 & 110.30 & 106.14 & 100.18 & 115.93 & 110.26 & 101.01 \\
\hline MOLT-4 & 97.31 & 83.48 & -1.61 & 9.76 & 3.99 & 36.08 & 98.63 & 106.18 & 108.68 & 110.50 & 102.08 & 96.07 \\
\hline RPMI-8226 & 104.44 & 89.35 & 8.62 & -11.88 & -0.08 & 55.63 & 100.96 & 107.04 & 96.92 & 104.39 & 100.71 & 103.82 \\
\hline SR & 94.95 & 86.34 & 17.49 & -3.51 & 2.64 & 38.47 & 102.08 & 102.81 & 100.59 & 107.29 & 95.10 & 92.08 \\
\hline \multicolumn{13}{|l|}{$\begin{array}{c}\text { Non-Small } \\
\text { Cell Lung } \\
\text { Cancer }\end{array}$} \\
\hline A549/ATCC & 100.66 & 97.94 & 20.05 & 26.37 & 40.00 & 61.53 & 99.63 & 100.43 & 94.07 & 99.29 & 88.97 & 92.29 \\
\hline HOP-62 & 91.79 & 88.80 & 20.57 & 44.24 & 26.74 & 71.07 & 107.44 & 110.27 & 100.46 & 97.06 & 100.11 & 99.80 \\
\hline HOP-92 & 97.54 & 55.36 & 38.66 & 4.62 & 12.92 & 93.48 & 103.83 & 102.24 & 112.38 & 95.91 & 112.12 & 119.07 \\
\hline NCI-H226 & 77.91 & 76.26 & 33.32 & 71.92 & -54.51 & 79.11 & 100.15 & 98.08 & 102.75 & 95.24 & 90.14 & 98.72 \\
\hline NCI-H23 & 98.46 & 95.03 & 12.46 & 48.79 & 0.50 & 84.87 & 104.58 & 104.78 & 104.13 & 102.53 & 100.60 & 105.95 \\
\hline NCI-H322M & 109.04 & 111.61 & 64.33 & 47.83 & 60.93 & 82.41 & 113.25 & 113.62 & 100.59 & 112.45 & 120.92 & 107.42 \\
\hline NCI-H460 & 101.43 & 96.41 & 9.89 & 26.11 & 21.50 & 78.22 & 104.65 & 107.58 & 104.04 & 105.33 & 101.10 & 103.32 \\
\hline NCI-H522 & 96.77 & 94.73 & 11.92 & 30.26 & -46.35 & 63.79 & 99.80 & 99.42 & 93.81 & 94.50 & 88.96 & 94.54 \\
\hline \multicolumn{13}{|l|}{ Colon Cancer } \\
\hline COLO 205 & 104.12 & 90.33 & 18.58 & 28.17 & 11.92 & 87.36 & 109.27 & 106.06 & 108.94 & 97.72 & 120.10 & 113.40 \\
\hline HCC-2998 & 113.44 & 125.00 & 30.69 & 40.46 & -42.18 & 109.78 & 116.92 & 117.02 & 99.78 & 108.63 & 100.99 & 101.69 \\
\hline HCT-116 & 100.08 & 92.15 & 15.20 & 7.67 & -56.86 & 72.47 & 99.11 & 102.65 & 103.09 & 112.65 & 95.64 & 98.11 \\
\hline HCT-15 & 108.95 & 101.25 & 18.27 & 6.39 & 2.76 & 69.54 & 110.84 & 107.84 & 98.61 & 98.47 & 91.84 & 90.29 \\
\hline HT29 & 104.37 & 94.32 & 32.43 & 2.24 & 0.52 & 76.99 & 105.50 & 98.23 & 95.98 & 98.30 & 90.03 & 91.22 \\
\hline KM12 & 102.76 & 101.06 & 18.93 & 14.10 & -32.31 & 57.68 & 104.00 & 104.10 & 107.39 & 108.60 & 113.05 & 110.46 \\
\hline SW-620 & 102.08 & 92.70 & 26.99 & 20.31 & -30.09 & 95.03 & 102.08 & 103.69 & 103.84 & 106.80 & 106.38 & 112.75 \\
\hline \multicolumn{13}{|l|}{ CNS Cancer } \\
\hline SF-268 & 98.05 & 90.01 & 42.42 & 48.73 & 12.64 & 70.55 & 104.16 & 102.79 & 101.06 & 107.58 & 110.27 & 105.88 \\
\hline SF-295 & 101.82 & 104.68 & 17.82 & 4.80 & 40.69 & 91.83 & 102.13 & 106.90 & 94.17 & 96.02 & 92.70 & 87.83 \\
\hline SNB-19 & 104.47 & 92.02 & 32.96 & 16.20 & -76.47 & 84.08 & 102.85 & 113.07 & 107.18 & 104.97 & 99.86 & 100.77 \\
\hline SNB-75 & 98.06 & 81.20 & 46.25 & 68.13 & -3.13 & 47.27 & 104.44 & 104.58 & 101.30 & 98.14 & 108.60 & 113.97 \\
\hline U251 & 99.49 & 81.02 & 18.31 & 5.40 & -31.11 & 60.02 & 99.27 & 96.94 & 96.04 & 96.73 & 96.20 & 98.57 \\
\hline \multicolumn{13}{|l|}{ Melanoma } \\
\hline LOX IMVI & 99.86 & 91.92 & 33.64 & -27.27 & -77.27 & 78.14 & 98.66 & 97.47 & 106.33 & 102.67 & 105.88 & 102.07 \\
\hline MALME-3M & 99.61 & 98.95 & 38.46 & -9.90 & 0.78 & 92.60 & 109.49 & 109.37 & 102.02 & 114.03 & 103.06 & 107.11 \\
\hline M14 & 99.68 & 97.11 & 19.31 & 37.26 & 7.30 & 79.40 & 110.29 & 102.33 & 104.47 & 94.84 & 95.05 & 98.56 \\
\hline MDA-MB-435 & 102.80 & 101.78 & 13.74 & -39.98 & -33.34 & 79.17 & 104.97 & 104.25 & 97.40 & 99.52 & 93.54 & 99.61 \\
\hline SK-MEL-28 & 114.13 & 106.32 & 44.13 & -11.92 & -31.58 & 88.26 & 115.55 & 108.44 & 113.30 & 108.85 & 104.25 & 101.01 \\
\hline SK-MEL-5 & 99.78 & 78.70 & 7.12 & 52.34 & -43.28 & 70.24 & 102.99 & 97.51 & 97.52 & 98.10 & 92.88 & 97.04 \\
\hline UACC-257 & 92.99 & 97.43 & 15.33 & 73.78 & 34.44 & 83.89 & 95.84 & 99.00 & 92.41 & 92.96 & 95.34 & 98.51 \\
\hline UACC-62 & 89.82 & 95.86 & 13.41 & -34.42 & -14.30 & 45.80 & 102.94 & 99.57 & 109.16 & 109.52 & 99.19 & 101.37 \\
\hline
\end{tabular}




\begin{tabular}{|c|c|c|c|c|c|c|c|c|c|c|c|c|}
\hline \multicolumn{13}{|l|}{$\begin{array}{l}\text { Ovarian } \\
\text { Cancer }\end{array}$} \\
\hline IGROV1 & 100.69 & 93.28 & 17.58 & 44.40 & -62.82 & 69.82 & 104.89 & 99.94 & 112.08 & 108.49 & 109.78 & 114.42 \\
\hline OVCAR-3 & 105.82 & 105.30 & 11.14 & 42.61 & -20.81 & 70.77 & 106.79 & 109.27 & 97.80 & 103.54 & 91.81 & 100.46 \\
\hline OVCAR-4 & $112 . .34$ & 98.51 & 85.59 & 72.85 & -16.00 & 119.12 & 128.13 & 105.20 & 95.04 & 98.21 & 87.87 & 98.16 \\
\hline OVCAR-5 & 96.15 & 93.11 & 18.24 & 31.43 & 19.42 & 76.04 & 97.65 & 97.79 & 102.44 & 97.13 & 95.29 & 98.86 \\
\hline OVCAR-8 & 102.88 & 96.02 & 36.17 & 45.08 & 37.64 & 72.79 & 102.05 & 108.96 & 108.60 & 107.36 & 96.87 & 104.78 \\
\hline $\begin{array}{c}\text { NCI/ADR- } \\
\text { RES }\end{array}$ & 87.34 & 83.46 & 38.21 & 66.42 & 56.69 & 69.51 & 104.75 & 103.94 & 101.30 & 96.47 & 104.74 & 108.00 \\
\hline SK-OV-3 & & & & & & & & & & & & \\
\hline \multicolumn{13}{|l|}{ Renal Cancer } \\
\hline $786-0$ & 106.81 & 109.40 & 50.39 & -27.85 & N/A & 83.90 & 106.39 & 103.55 & 93.29 & 100.35 & 90.25 & 92.37 \\
\hline A498 & 98.67 & 88.94 & 24.54 & 35.41 & 24.52 & 51.51 & 105.00 & 97.78 & 76.51 & 71.73 & 65.35 & N/A \\
\hline ACHN & 111.96 & 111.40 & 22.43 & 58.77 & -15.09 & 80.72 & 114.90 & 115.42 & 106.81 & 100.38 & 98.42 & 99.63 \\
\hline CAKI-1 & 94.57 & 86.32 & 20.58 & 33.85 & 18.67 & 79.66 & 96.10 & 108.56 & 90.31 & 95.26 & 86.85 & 94.80 \\
\hline RXF 393 & 115.04 & 98.74 & 65.65 & -39.72 & -91.21 & 81.98 & 101.64 & 108.23 & 107.83 & 104.83 & 99.82 & 98.58 \\
\hline SN12C & 100.36 & 90.98 & 26.41 & 60.11 & -3.83 & 79.10 & 109.76 & 102.35 & 100.92 & 100.48 & 100.40 & 104.22 \\
\hline TK-10 & 116.14 & 109.44 & 31.96 & 51.66 & 27.53 & 84.79 & 109.81 & 104.97 & 90.61 & 97.25 & 88.69 & 83.19 \\
\hline UO-31 & 78.63 & 57.84 & 18.97 & 51.21 & -51.60 & 51.36 & 91.35 & 96.00 & 92.23 & 107.89 & 95.92 & 102.32 \\
\hline $\begin{array}{l}\text { Prostate } \\
\text { Cancer }\end{array}$ & 91.56 & 72.64 & 1.46 & 22.81 & -29.02 & 38.97 & 92.56 & 101.38 & 100.95 & 99.43 & 98.99 & 100.32 \\
\hline $\begin{array}{c}\text { PC-3 } \\
\text { DU-145 }\end{array}$ & 113.58 & 101.68 & 33.71 & 57.80 & 11.15 & 81.39 & 104.50 & 99.03 & 100.32 & 111.19 & 106.90 & 110.75 \\
\hline \multicolumn{13}{|l|}{ Breast Cancer } \\
\hline MCF7 & 92.95 & 84.53 & 5.46 & 24.87 & 14.27 & 72.69 & 102.79 & 105.33 & 92.06 & 96.67 & 86.47 & 89.07 \\
\hline MDA-MB & 93.31 & 73.03 & 36.57 & 23.06 & -25.22 & 52.88 & 107.72 & 107.61 & 113.82 & 127.47 & 120.61 & 117.24 \\
\hline 2J1/AICC & 104.82 & 89.72 & 58.32 & 3.43 & 37.47 & 76.42 & 112.75 & 108.80 & 106.23 & 105.12 & 110.06 & 108.69 \\
\hline HS 578 & 106.63 & 92.23 & 15.70 & 11.41 & -10.33 & 71.99 & 111.77 & 103.78 & 66.68 & 75.55 & N/A & N/A \\
\hline BT-5 & 97.57 & 79.82 & -6.32 & 8.43 & 10.20 & 57.90 & 99.99 & 101.10 & 87.22 & 90.54 & 82.33 & 95.97 \\
\hline $\begin{array}{c}\text { T-47D } \\
\text { MDA-MBA- } \\
468\end{array}$ & 101.43 & 103.76 & 0.17 & 6.44 & -76.16 & 68.60 & 97.68 & 93.33 & 103.56 & 98.82 & 84.75 & 87.37 \\
\hline Mean & 100.80 & 93.03 & 25.03 & 23.23 & -6.99 & 72.80 & 104.90 & 104.15 & 100.54 & 101.90 & 99.05 & 101.38 \\
\hline
\end{tabular}

* Results are presented as percent cell growth promotion.

* Values less than $10 \%$ growth promotion are presented in bold. 


\subsubsection{In vitro 5 log dose full NCI 60 cell panel assay.}

The three compounds $(\mathbf{6 b}, \mathbf{6 e} \boldsymbol{\&} \mathbf{7 b})$ were selected by NCI for further 5 log dose screening against full NCI 60 cell panel. All investigated compounds revealed potent antiproliferative activity against most of the tested cell lines representing the nine

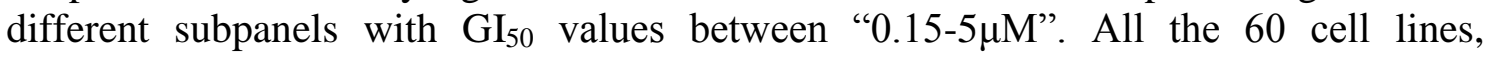
representing nine tumor subpanels, were incubated at five different concentrations $(0.01,0.1,1,10 \& 100 \mu \mathrm{M})$ of each of the tested compounds. The outcomes were used to create $\log$ concentration vs $\%$ growth inhibition curves and three response parameters ( $\mathrm{GI}_{50}$, TGI and $\mathrm{LC}_{50}$ ) were calculated for each cell line, (Table 2). The biarylurea-based derivative $(\mathbf{6 b})$ linked to the phthalazine core via an $\mathrm{NH}$ linker exhibited remarkable $\mathrm{GI}_{50}$ between " $0.82-5 \mu \mathrm{M}$ " against the investigated cell panels with submicromolar $\mathrm{GI}_{50}$ values of $0.82 \& 0.95 \mu \mathrm{M}$ against the melanoma LOX IMVI \&UACC-62 cell lines, respectively. Moreover, its analogue (6e) showed potent single digit micromolar $\mathrm{GI}_{50}$ values between "1.61-4.77 $\mu \mathrm{M}$ "against all the tested cell lines

With regard to the sensitivity against some individual cell lines, compound (7b) exhibited the highest broad spectrum submicromolar inhibitory activity against most of the tested cell lines specially those of leukemia, colon, melanoma and breast cancer cell panels with $\mathrm{GI}_{50}$ values $(0.15-2.81)$ (Table 2).

As for the selectivity of the test compounds towards some specific tumor subpanels which is calculated based on the ratio obtained by dividing the full panel MID (the average sensitivity of all cell lines toward the test agent) by their individual subpanel MID (the average sensitivity of all cell lines of a particular subpanel toward the test agent) (M.C. Alley, 1988,M.R. Grever, 1992). As per this criterion, the test compounds $(\mathbf{6 b}, \mathbf{6 e} \& \mathbf{7 b})$ were regarded to be more selective against leukemia, renal, melanoma and breast cancer subpanel. It was reported that levels of VEGFR are over expressed in cell lines derived from leukemia, melanoma and renal cancer (Min Sun, 2010). Thus, the cytotoxicity patterns of these compounds may support the original VEGFR targeting strategy.

Table 2: In vitro NCI $5 \log$ dose results for compounds $(\mathbf{6 b}, \mathbf{6 e} \boldsymbol{\&} \mathbf{7 b})$ in $\mu \mathrm{M}$ against 60 cell panel.

\begin{tabular}{|c|c|c|c|c|c|c|c|c|c|c|}
\hline \multirow[t]{2}{*}{ Panel } & \multirow[t]{2}{*}{ Cell Line } & \multicolumn{3}{|c|}{ Compound $6 \mathrm{~b}$} & \multicolumn{3}{|c|}{ Compound 6e } & \multicolumn{3}{|c|}{ Compound $7 \mathrm{~b}$} \\
\hline & & $\mathbf{G I}_{50}$ & TGI & $\mathbf{L C}_{\mathbf{5 0}}$ & $\mathbf{G I}_{50}$ & TGI & $\mathbf{L C}_{50}$ & $\mathbf{G I}_{50}$ & TGI & $\mathbf{L C}_{\mathbf{5 0}}$ \\
\hline \multirow[t]{6}{*}{ Leukemia } & CCRF-CEM & 2.57 & 17.0 & $>100$ & 2.38 & 5.99 & $>100$ & 0.32 & ND & $>100$ \\
\hline & HL-60(TB) & 2.42 & 7.00 & $>100$ & 2.03 & 4.18 & 8.64 & 1.08 & 13.4 & $>100$ \\
\hline & K-562 & 1.68 & 26.4 & $>100$ & 2.20 & 4.67 & 9.92 & 0.37 & $>100$ & $>100$ \\
\hline & MOLT-4 & 2.09 & 6.36 & $>100$ & 2.36 & 6.00 & $>100$ & 0.37 & $>100$ & $>100$ \\
\hline & RPMI-8226 & 2.50 & 8.75 & $>100$ & 2.60 & 6.48 & $>100$ & 0.48 & 4.58 & $>100$ \\
\hline & SR & 3.89 & 23.3 & $>100$ & 2.56 & 9.55 & $>100$ & 0.40 & $>100$ & $>100$ \\
\hline \multirow{4}{*}{$\begin{array}{l}\text { Non-Small } \\
\text { Cell Lung } \\
\text { Cancer }\end{array}$} & A549/ATCC & 3.03 & 19.3 & $>100$ & 3.24 & 8.59 & 37.9 & 2.81 & 11.5 & $>100$ \\
\hline & EKVX & 2.95 & 25.3 & $>100$ & 3.47 & 17.9 & 87.8 & 1.61 & 4.50 & $>100$ \\
\hline & HOP-62 & 3.00 & 14.9 & 74.9 & 1.81 & 3.70 & 7.56 & 1.09 & 4.32 & 47.7 \\
\hline & HOP-92 & 2.55 & 7.26 & $>100$ & 2.56 & 6.60 & 42.0 & 1.64 & 4.37 & 17.1 \\
\hline
\end{tabular}




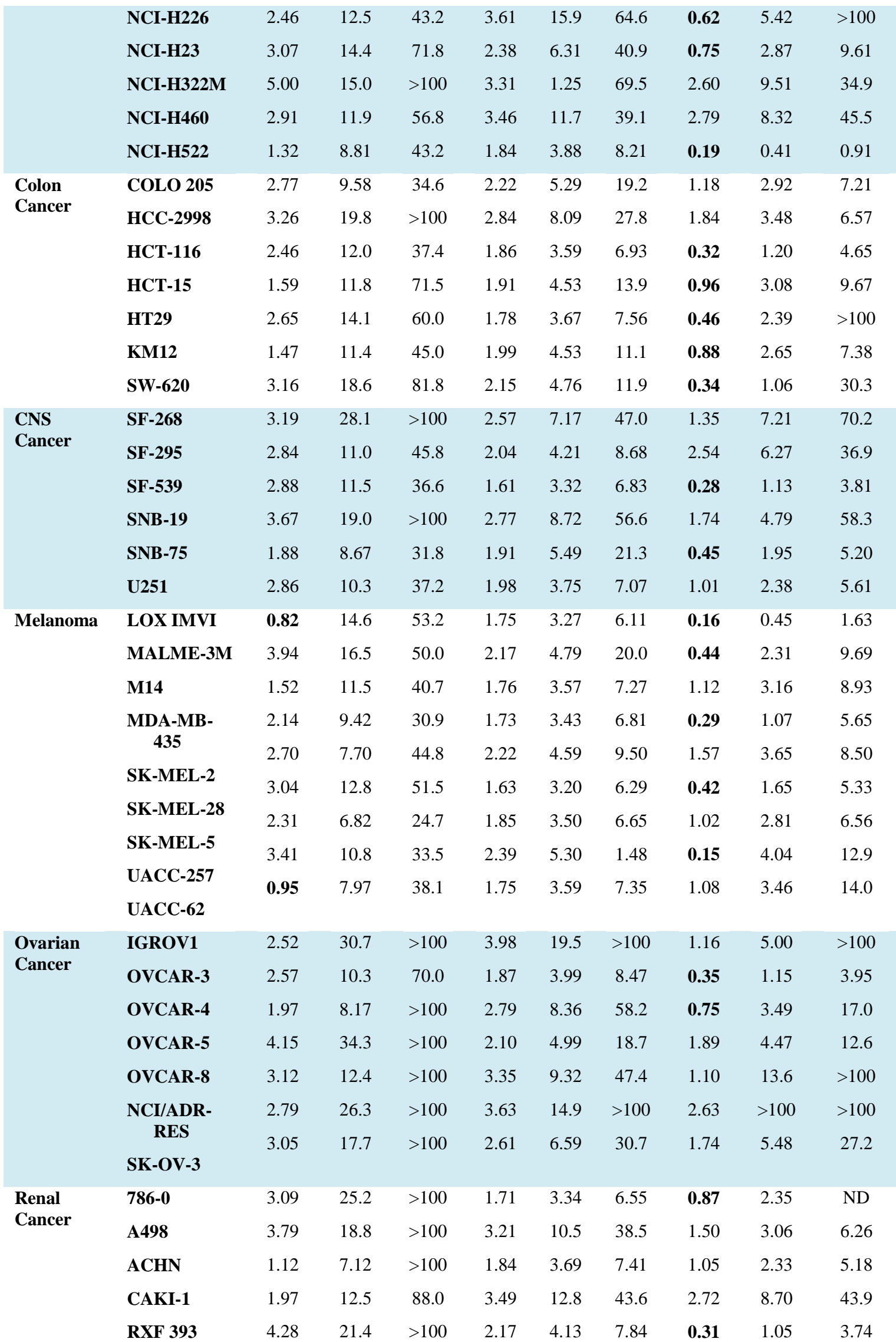




$\begin{array}{lllllllllll} & \text { SN12C } & 4.58 & 37.2 & >100 & 2.86 & 9.41 & 60.1 & 1.03 & 3.58 & >100 \\ & \text { TK-10 } & 5.03 & 24.4 & >100 & 3.19 & 9.42 & 33.7 & 2.12 & 4.28 & 8.64 \\ \text { Prostate } & \text { UO-31 } & 1.90 & 15.8 & >100 & 2.14 & 6.01 & 31.8 & 1.29 & 2.67 & \text { ND } \\ \text { Cancer } & \text { DU-3 } & 2.32 & 11.0 & 55.4 & 3.49 & 11.9 & 62.7 & 1.64 & 6.08 & 35.6 \\ & & 3.17 & 26.9 & >100 & 4.77 & 19.5 & 66.9 & \mathbf{0 . 7 3} & 2.08 & 4.88 \\ \text { Breast } & \text { MCF7 } & 1.43 & 8.32 & 64.1 & 2.21 & 10.9 & 68.7 & \mathbf{0 . 3 2} & 1.89 & \text { ND } \\ \text { Cancer } & \text { MDA-MB } & 3.40 & 15.9 & 64.9 & 2.38 & 5.94 & 33.9 & \mathbf{0 . 3 9} & 3.68 & 42.4 \\ & \quad 231 / A T C & 3.83 & 27.7 & >100 & 2.52 & 6.40 & >100 & \mathbf{0 . 6 9} & 47.0 & >100 \\ & \text { C } & 2.15 & 9.28 & >100 & 2.21 & 5.55 & 66.0 & 2.08 & 7.43 & 58.1 \\ & \text { HS 578T } & 1.03 & 5.35 & 79.3 & 2.06 & 5.08 & 56.4 & \mathbf{0 . 2 4} & 7.68 & >100 \\ & \text { BT-549 } & 2.57 & 9.47 & >100 & 2.84 & 7.43 & 36.2 & \mathbf{0 . 7 5} & 2.52 & 7.18 \\ & \text { T-47D } & & & & & & & & & \end{array}$

*The $\mathrm{GI}_{50}$ value (growth inhibitory activity) corresponds to the concentration of the compound causing 50\% decrease in net cell growth.

*The TGI value (cytostatic activity) is the concentration of the compound resulting in total growth inhibition.

$* \mathrm{LC}_{50}$ value (cytotoxic activity) is the concentration of the compound causing net $50 \%$ loss of initial cells at the end of the incubation period of $48 \mathrm{~h}$.

*Submicromolar $\mathrm{GI}_{50}$ values are presented in bold.

\subsubsection{In vitro VEGFR tyrosine kinase activity}

The VEGFR tyrosine kinase assays were performed at BPS Bioscience (www.bpsbioscience.com). All the synthesized compounds representing the four series of phthalazine based derivatives were evaluated for their ability to inhibit VEGFR-2 tyrosine kinase at single dose of $10 \mu \mathrm{M}$. At this concentration, the biarylurea based derivative (6c) incorporating a 3-chloro-4-triflouromethyl substituent on the terminal phenyl ring has demonstrated a significant inhibition of $70 \%$ for the VEGFR kinase activity, however its analogue 7c exhibited moderate VEGFR inhibition percent of $47 \%$. The mean percent inhibition of the compounds on VEGFR at $10 \mu \mathrm{M}$ concentration are presented in Table 3.

Investigating the results of VEGFR inhibitory activity among the newly synthesized phthalazines, it was revealed that derivatives bearing a substituted biarylurea motif and linked to the phthalazine nucleus via amino linker (6a-f)generally tended to exhibit higher inhibition percent than their ether linked analogues (7a-f).And within these biarylurea based derivatives, the 4-chloro-3-triflouromethyl derivatives, having a substitution pattern similar to that of sorafenib, seemed to demonstrate the highest VEGFR inhibition percent. Unfortunately, neither of the amide based phthalazines nor the piperazine based ones exhibited any significant VEGFR inhibition.

Furthermore, compound (6c)which exhibited 70\% VEGFR kinase inhibition was tested at 5 dose concentration to calculate its $\mathrm{IC}_{50}$. Its profiling data against VEGFR2 showed increased inhibition of VEGFR activity with increasing concentration with $\mathrm{IC}_{50}=13.4 \mu \mathrm{M}$. 
Table 1: The VEGFR inhibition percent of the synthesized phthalazines at $10 \mu \mathrm{M}$ concentration.

\begin{tabular}{|cccc}
\hline Compound & $\begin{array}{c}\text { \% } \\
\text { inhibition }\end{array}$ & Compound & $\begin{array}{c}\text { \% } \\
\text { inhibition }\end{array}$ \\
\hline 5a & 4 & $\mathbf{7 d}$ & 10 \\
\hline $\mathbf{5 b}$ & 8 & $\mathbf{7 e}$ & 14 \\
\hline $\mathbf{5 c}$ & 12 & $\mathbf{7 f}$ & 21 \\
\hline $\mathbf{5 d}$ & 15 & $\mathbf{8 a}$ & 13 \\
\hline 6a & 13 & $\mathbf{8 b}$ & 8 \\
\hline 6b & 20 & $\mathbf{8 c}$ & 9 \\
\hline 6c & 70 & $\mathbf{8 d}$ & 5 \\
\hline 6d & 15 & $\mathbf{8 e}$ & 9 \\
\hline 6e & 19 & $\mathbf{8 f}$ & 14 \\
\hline 6f & 32 & $\mathbf{8 g}$ & 13 \\
\hline 7a & 5 & $\mathbf{8 h}$ & 9 \\
\hline 7b & 13 & $\mathbf{8 i}$ & 6 \\
\hline 7c & 47 & $\mathbf{8 j}$ & 10 \\
\hline Staurosporine & 100 & & \\
\hline
\end{tabular}

\subsection{Molecular modeling studies}

Molecular docking study was performed using Accelry's Discovery Studio 2.5 software CDOCKER protocol through docking of the synthesized compounds in the VEGFR-2 kinase active site (Accelry's Discovery Studio 2.5, 2010). Docking study aimed to interpret the VEGFR-2 inhibitory activity of the investigated molecules and gain further insight into their binding affinities and binding interactions with the kinase active site. The coordinates of the VEGFR2 structure were obtained from the crystal structure of VEGFR complexedwith sorafenib as its inhibitor (PDB code 4ASD), which revealed the hydrogen bond interactions between the $\mathrm{NH}$ and $\mathrm{CO}$ motifs of urea moiety with the backbone of Asp1046 and the carboxylic acid moiety of Glu885, respectively, as well as a H-bond with Cys919 residue in the hinge region of the kinase active site(D.M. Sammond, 2005).

The docking algorithm was validated via redocking of the co-crystallized ligand (sorafenib) in the VEGFR-2 active site where the docking procedure was able to retrieve the co-crystallized pose with RMSD value of $2.03 \mathrm{~A}^{\circ}$.

Docking of the investigated compounds revealed that the substituted urea based derivatives $(\mathbf{6 c} \boldsymbol{\&} \mathbf{7 c})$ were capable of occupying the ATP binding site of the VEGFR-2 kinase while maintaining the essential key interactions. Thus, a hydrogen bond has been observed between carbonyl group of the urea motif with the backbone NH of Asp 1046 where as the urea $\mathrm{NH}$ groups have been engaged in two hydrogen bond interactions 
with the carboxylic acid of Glu 885. However, the substituted biarylurea based derivatives (6c \& 7c)missed the key H-bond interaction with Cys919, which may explain their relatively lower activity against VEGFR-2 inhibitory activity. On the contrary, the piperazine based derivatives (8a-j) failed to form the essential H-bond interactions with the VEGFR active site which might explain their poor inhibitory activity. One of the best scored poses of the urea based compounds (6c \& 7c) are presented in Fig 3 \& 4.

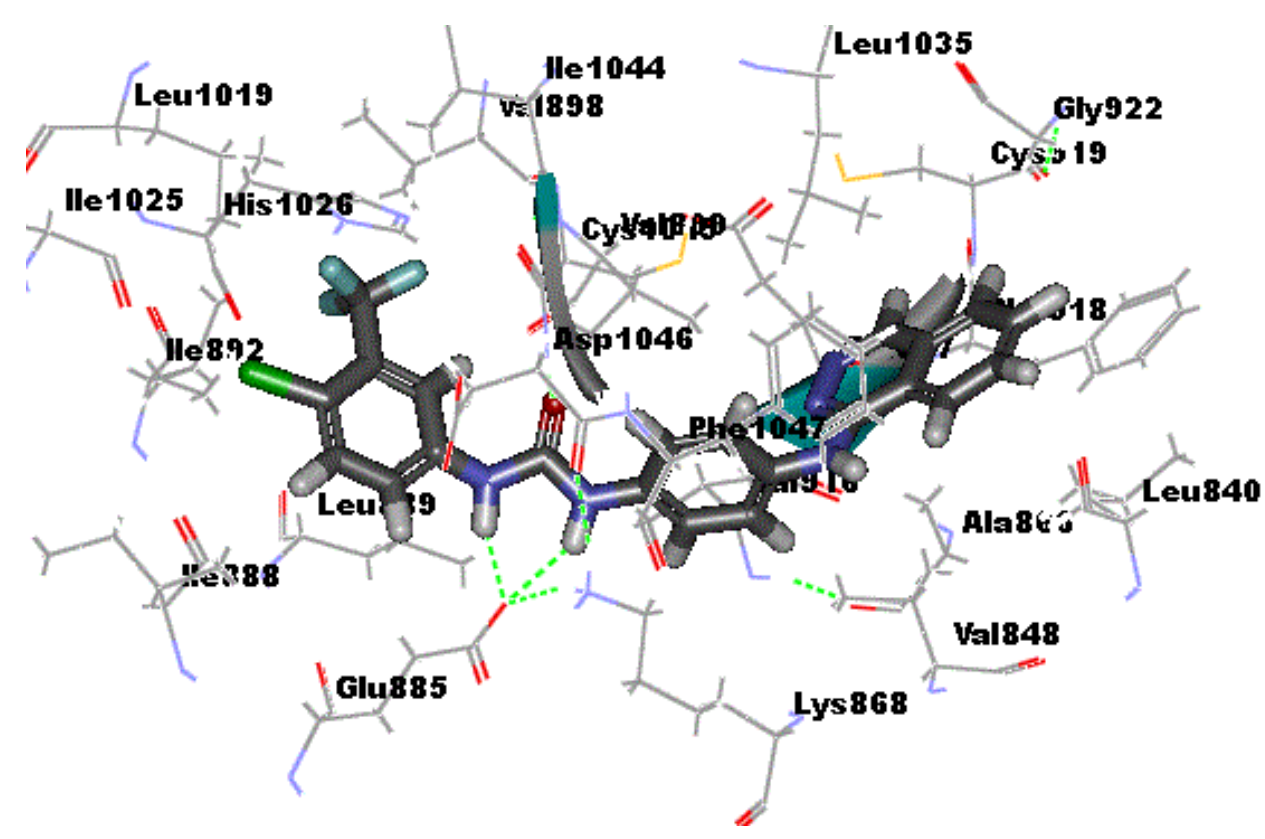

Fig. 3. Docking of compound $\mathbf{6 c}$ in the ATP binding site of VEGFR-2 kinase(PDB code 4ASD); showing key hydrogen bonding interactions (dotted lines) betweenCO and $\mathrm{NH}$ motifs of urea moiety with the backbone of Asp1046 and the carboxylic acid of Glu885 residues. 


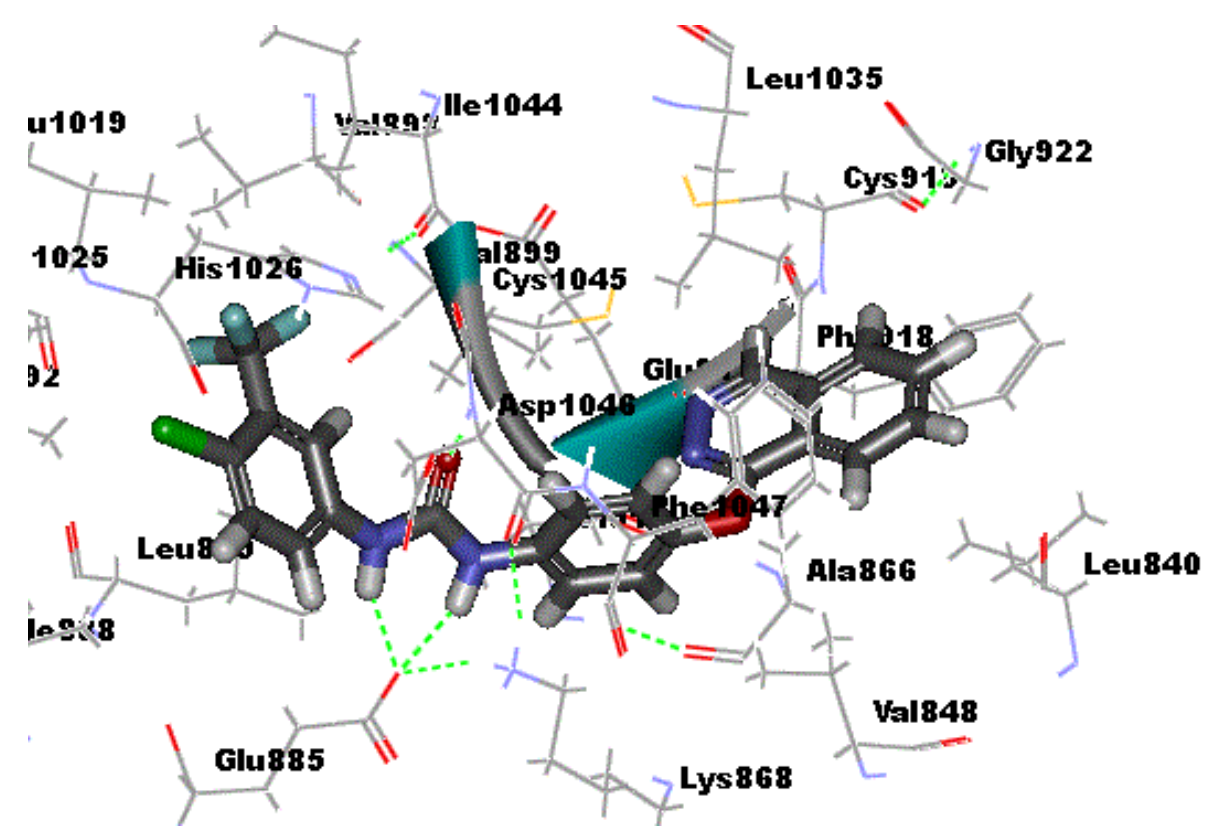

Fig. 4.Docking of compound 7c in the ATP binding site of VEGFR-2 kinase (PDB code 4ASD); showing key hydrogen bonding interactions (dotted lines) between $\mathrm{CO}$ and $\mathrm{NH}$ motifs of urea moiety with the backbone of Asp1046and the carboxylic acid of Glu885 residues.

\section{Conclusion}

Four series of phthalazine based derivatives bearing biarylamides(5a-d), biarylureas (6a-f) and (7a-f)or a substituted piperazine moiety at position 1 of the phathalazine nucleus (8a-j) were designed, synthesized as targeted anticancer agents targeting VEGFR kinase. Twelve of the synthesized compounds were selected by NCI for antiproliferative screening against full NCI 60 cell panel at single dose $10 \mu \mathrm{M}$. Three of the tested phthalazine bearing a biarylurea tail ( $6 \mathbf{6 , 6 e}$ and $7 \mathbf{b})$ exhibited excellent broad spectrum cell growth inhibition between (100\% to 191\%) against a variety of NCI cell lines, thus were selected for further screening at $5 \log$ doses against full NCI 60 cell panel. The latter $5 \log$ doses screening confirmed their excellent in vitro cell growth inhibitory activity with $\mathrm{GI}_{50}$ between $0.15-5 \mu \mathrm{M}$ against most of the investigated cell lines specially those of leukemia, renal, melanoma and breast cancer cell lines. Furthermore, the synthesized phthalazines were evaluated for their VEGFR-2 inhibitory activity, which revealed a significant inhibition of $70 \%$ exhibited by the 4chloro-3-triflouromethyl substituted biarylurea based derivative (6c). Molecular docking study of $\mathbf{6 c}$ on VEGFR-2 kinase active site revealed its ability to form the essential $\mathrm{H}$ bond interactions with Glu 885 and Asp1046 key residues in the VEGFR-2 active site. 


\section{Experimental}

\subsection{Chemistry}

Starting materials and reagents were purchased from Sigma - Aldrichor Acros Organics. Melting points were recorded on Gallen Kamp apparatus and were uncorrected. FT-IR spectra were recorded on a Shimadzu IR 435 spectrophotometer. ${ }^{1} \mathrm{HNMR}$ spectra were recorded in $\delta$ scale given in ppm on a Varian $400 \mathrm{MHz}$ spectrophotometer or a Varian $300 \mathrm{MHz}$ spectrophotometer. Coupling patterns aredescribed as follows: s, singlet; $\mathrm{d}$, doublet, dd, doubled doublet; $\mathrm{t}$, triplet; $\mathrm{m}$, multiplet. $J$ describes a coupling constant. The coupling constants were rounded off to one decimal place. MS spectra mass were recorded on Hewlett Packard 5988 spectrometer $(70 \mathrm{eV})$. Elemental analyzes were performed at the Microanalytical Center,

Al-Azhar University. Compounds 1a-c(Stout\& Matier\& Barcelon-Yang\& Reynolds\& Brown, 1985), 2a,b(Smolyar\& Yutilov, 2008) and 3a,b(Neumann, 1893) were prepared following reported procedures.

\subsubsection{Synthesis of $N^{1}$-(4-Arylphthalazin-1-yl)benzene-1,4-diamines $(4 a, b)$}

General procedure:

Benzene diamine $(0.33 \mathrm{~g}, 3.12 \mathrm{mmol}, 3$ equiv $)$ and the respective
chlorophthalazine

(2.08 mmol, 2equiv) were treated with $2-\mathrm{BuOH}(7.5 \mathrm{~mL})$ in a tube and heated to 110 ${ }^{\circ} \mathrm{C}$. The reaction quickly became a solid, yellow mass. After four hours, the reaction was cooled and diluted with water. The resultant slurry was then partitioned between equal volumes of $\mathrm{DCM}$ and $1 \mathrm{~N} \mathrm{NaOH}(15 \mathrm{~mL})$. The aqueous layer was extracted into DCM $(2 \times 15 \mathrm{~mL})$. The combined organic layers were dried over anhydrous sodium sulfate, filtered, and concentrated in vacuo. The resulting orange solid was crystallized from (EtOAc/pet ether 1:1) to afford the title compounds $(\mathbf{4 a , b})$ as an orange crystals.

\subsubsection{N1-(Phthalazin-1-yl)benzene-1,4-diamine (4a)}

Yield(0.21 g, 91\%) ;mp 284-286 ${ }^{\circ} \mathrm{C} ;{ }^{1}$ HNMR (300 MHz, DMSO-d $)$ ): $\delta 9.15$ $\left(1 \mathrm{H}, \mathrm{s},-\mathrm{NH} \mathrm{D}_{2} \mathrm{O}\right.$ exchangeable), $9.04\left(2 \mathrm{H}, \mathrm{s},-\mathrm{NH}_{2} \mathrm{D}_{2} \mathrm{O}\right.$ exchangeable), $\delta 8.95-8.92$ $(2 \mathrm{H}, \mathrm{d}, J=9 \mathrm{~Hz}$, phthalazine), $\delta 8.18-8.15(2 \mathrm{H}, \mathrm{d}, J=9 \mathrm{~Hz}$, phthalazine), $\delta 7.97(1 \mathrm{H}, \mathrm{s}$, phthalazine), $\delta$ 7.65-7.62 (2H,d, $J=9 \mathrm{~Hz}, \mathrm{ArH}), \delta 6.97-6.83(2 \mathrm{H}, \mathrm{d}, J=9 \mathrm{~Hz}, \mathrm{ArH}) ; \mathrm{FT}-$ IR (v́ max, $\left.\mathrm{cm}^{-1}\right)$ : $3400\left(\mathrm{NH}_{2}\right), 3329(\mathrm{NH})$; MS (Mwt.: 236.11): m/z $236.00(\mathrm{M}+$, 43.00\%), 212.00 (100.00\%), 118.00 (54.00\%), 56.00 (70.00\%); Anal. Calcd for $\mathrm{C}_{14} \mathrm{H}_{12} \mathrm{~N}_{4}$ : C, 71.17; H, 5.12; N, 23.71; Found: C, 71.34; H, 5.17; N, 23.96

\subsubsection{N1-(4-Methylphthalazin-1-yl)benzene-1,4-diamine (4b)}

Yield (0.22 g, 88\%) ;mp 240-242 ${ }^{\circ} \mathrm{C} ;{ }^{1}$ HNMR (300 MHz, DMSO-d $)$ ): $\delta 8.88$ $\left(1 \mathrm{H}, \mathrm{s},-\mathrm{NH} \mathrm{D}_{2} \mathrm{O}\right.$ exchangeable), $8.85\left(2 \mathrm{H}, \mathrm{s},-\mathrm{NH}_{2} \mathrm{D}_{2} \mathrm{O}\right.$ exchangeable), $\delta$ 8.13-8.08 $(2 \mathrm{H}, \mathrm{d}, J=7 \mathrm{~Hz}$, phthalazine), $\delta 7.95-7.92(2 \mathrm{H}, \mathrm{d}, J=7 \mathrm{~Hz}$, phthalazine), $\delta 7.46-7.43$ $(2 \mathrm{H}, \mathrm{d}, J=9 \mathrm{~Hz}, \mathrm{ArH}), \delta 6.83-6.76(2 \mathrm{H}, \mathrm{d}, J=9 \mathrm{~Hz}, \mathrm{ArH}), \delta 2.48\left(3 \mathrm{H}, \mathrm{s}, \mathrm{CH}_{3}\right) ; \mathrm{FT}-\mathrm{IR}(v ́$ $\left.\max , \mathrm{cm}^{-1}\right): 3385\left(\mathrm{NH}_{2}\right), 3321(\mathrm{NH})$; MS (Mwt.: 250.12): m/z $250.00(\mathrm{M}+, 50.00 \%)$, 249.00 (100.00\%), 108.00 (60.92\%), 65.00 (77.59\%); Anal. Calcd for $\mathrm{C}_{15} \mathrm{H}_{14} \mathrm{~N}_{4}: \mathrm{C}$, 71.98; H, 5.64; N, 22.38; Found: C, 72.09; H, 5.78; N, 22.52. 


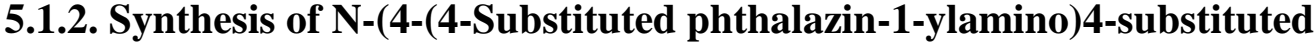 phenyl)benzamide (5a-d)}

General procedure:

To a stirred solution of the respective N1-(4-arylphthalazin-1-yl)benzene-1,4diamine (4a,b) (10.0 mmol, lequiv) and triethylamine $(1.1 \mathrm{~mL}, 10.0 \mathrm{mmol})$ in acetonitrile $(20 \mathrm{~mL})$, the respective benzoyl chloride (viz.; benzoyl chloride, 4chlorobenzoyl chloride) (10.0 mmol, 1equiv) was added and the mixture was heated under reflux for $6 \mathrm{~h}$, until the disappearance of starting material as judged by TLC $\left(\mathrm{CHCl}_{3} / \mathrm{CH}_{3} \mathrm{OH}\right.$ 9.5:0.5). The reaction mixture was filtered and then the filtrate was concentrated in vacuo, to afford the crude product which was purified by flash column chromatography (EtOAc/pet ether 9:1) to afford 5a-d as yellow crystals.

\subsubsection{1. $\mathrm{N}$-(4-(Phthalazin-1-ylamino)phenyl)benzamide (5a)}

Yield $(0.17 \mathrm{~g} ; 50 \%), \mathrm{mp} 142-144^{\circ} \mathrm{C} ;{ }^{1}$ HNMR(400 MHz, DMSO-d 6 ): $\delta 9.66$ $(1 \mathrm{H}, \mathrm{s}$,

-NH $\mathrm{D}_{2} \mathrm{O}$ exchangeable $), \delta 9.12\left(1 \mathrm{H}, \mathrm{s},-\mathrm{NH} \mathrm{D}_{2} \mathrm{O}\right.$ exchangeable $), \delta 8.62(1 \mathrm{H}, \mathrm{s}, J=8$ Hz,phthalazine), $\delta$ 8.11-8.08 (2H,d, $J=7.6 \mathrm{~Hz}, \mathrm{Ar}-\mathrm{H}), \delta 7.98-7.96(2 \mathrm{H}, \mathrm{d}, J=8 \mathrm{~Hz}$, phthalazine), $\delta$ 7.93-7.88 (2H, m,phthalazine), $\delta$ 7.64-7.62 (1H,m,Ar-H), $\delta$ 7.62-7.60 $(2 \mathrm{H}, \mathrm{d}, J=7.6 \mathrm{~Hz}, \mathrm{Ar}-\mathrm{H}), \delta$ 7.59-7.57 $(2 \mathrm{H}, \mathrm{d}, J=6.8 \mathrm{~Hz}, \mathrm{Ar}-\mathrm{H}), \delta$ 7.50-7.48 (2H, m,ArH); FT-IR (v́ $\left.\max , \mathrm{cm}^{-}{ }^{1}\right): 3550,3510(2 \mathrm{NH}), 1649(\mathrm{C}=\mathrm{O})$; MS (Mwt.: 340.38): $\mathrm{m} / \mathrm{z}$ $340.15\left[\mathrm{M}^{+}, 1.58 \%\right), 138.05(2.70 \%), 86.10(100 \%)$; Anal. Calcd for $\mathrm{C}_{21} \mathrm{H}_{16} \mathrm{~N}_{4} \mathrm{O}: \mathrm{C}$, 74.10; H, 4.74; N, 16.46; Found: C, 74.34; H, 4.80; N, 16.58

\subsubsection{4-Chloro-N-(4-(phthalazin-1-ylamino)phenyl)benzamide (5b)}

Yield (0.20g; 54\%), mp 156- $158^{\circ} \mathrm{C} ;{ }^{1} \mathbf{H N M R ( 4 0 0 ~ M H z , ~ D M S O - d _ { 6 } ) : \delta} 10.50$ $\left(1 \mathrm{H}, \mathrm{s},-\mathrm{NH} \mathrm{D} \mathrm{D}_{2} \mathrm{O}\right.$ exchangeable), $\delta 9.15\left(1 \mathrm{H}, \mathrm{s},-\mathrm{NH} \mathrm{D}_{2} \mathrm{O}\right.$ exchangeable), $\delta 8.99(1 \mathrm{H}, \mathrm{s}$, phthalazine $), \delta 8.11-8.08(2 \mathrm{H}, \mathrm{d}, J=9 \mathrm{~Hz}, \mathrm{Ar}-\mathrm{H}), \delta 7.94-7.92(2 \mathrm{H}, \mathrm{d}, J=7.6 \mathrm{~Hz}$, phthalazine), $\delta 7.91-7.90(2 \mathrm{H}, \mathrm{d}, J=7.6 \mathrm{~Hz}$ phthalazine), $\delta 7.56-7.54$ (2H,d, $J=9 \mathrm{~Hz}, \mathrm{Ar}-$ $\mathrm{H}), \delta$ 7.53-7.51 (2H,d, J= 7.5 Hz, Ar-H), $\delta$ 7.31-7.28 (2H,m,Ar-H); FT-IR (v́ max, cm$\left.{ }^{1}\right)$ : 3355, $3310(2 \mathrm{NH}), 1640(\mathrm{C}=\mathrm{O})$; MS (Mwt.: 374.82): $\mathrm{m} / \mathrm{z} 375.00(\mathrm{M}+, 1.57 \%)$, 245.00 (2.41\%), 139.05 (46.44\%), 111.10 (25.30), 64.00 (100.00\%); Anal. Calcd for $\mathrm{C}_{21} \mathrm{H}_{15} \mathrm{ClN}_{4} \mathrm{O}$ : C, 67.29; H, 4.03; N, 14.95; Found: C, 67.52; H, 4.08; N, 15.22.

\subsubsection{3. $N$-(4-(4-Methylphthalazin-1-ylamino)phenyl)benzamide(5c)}

Yield (0.24 g; 68\%), mp 283-285 ${ }^{\circ}$; ${ }^{1}$ HNMR(400 MHz, DMSO-d 6 ): $\delta 10.50$ (1H, s,-NH $\mathrm{D}_{2} \mathrm{O}$ exchangeable), $\delta 10.40$ (1H,s, -NH $\mathrm{D}_{2} \mathrm{O}$ exchangeable), $\delta$ 8.27-8.24 $(2 \mathrm{H}, \mathrm{d}, J=7.6 \mathrm{~Hz}$, phthalazine), $\delta 8.02-8.00(2 \mathrm{H}, \mathrm{m}, \mathrm{Ar}-\mathrm{H}), \delta$ 7.99-7.97 $(2 \mathrm{H}, \mathrm{d}, J=7.6$ $\mathrm{Hz}$, phthalazine), $\delta$ 7.77-7.73 $(1 \mathrm{H}, \mathrm{d}, J=9.2 \mathrm{~Hz}, \mathrm{Ar}-\mathrm{H}), \delta 7.63-7.61(2 \mathrm{H}, \mathrm{d}, J=7.2 \mathrm{~Hz}$, Ar-H), $\delta$ 7.59-7.56 (2H,d, $J=7.6 \mathrm{~Hz}, \mathrm{Ar}-\mathrm{H}), \delta$ 7.54-7.51 (2H, m,Ar-H), $\delta 2.91(3 \mathrm{H}, \mathrm{s}$, $\mathrm{CH}_{3}$ ); FT-IR (v́ max, $\mathrm{cm}^{-1}$ ): 3331, $3257(2 \mathrm{NH}), 1649(\mathrm{C}=\mathrm{O})$; MS (Mwt.: 354.15):m/z $354.95(\mathrm{M}+, 1.18 \%), 315.95$ (15.90\%), 105.00 (100.00\%); Anal. Calcd for $\mathrm{C}_{22} \mathrm{H}_{18} \mathrm{~N}_{4} \mathrm{O}$ : C, 74.56; H, 5.12; N, 15.81; Found: C, 74.78; H, 5.19; N, 16.04 


\subsubsection{4-Chloro-N-(4-(4-methylphthalazin-1-ylamino)phenyl)benzamide (5d)}

Yield (0.20g; 51\%), mp $147-149^{\circ} \mathrm{C} ;{ }^{1}$ HNMR(400 MHz, DMSO-d 6 ): $\delta 10.65$ (1H, s,-NH D $\mathrm{D}_{2} \mathrm{O}$ exchangeable), $\delta 10.45$ (1H, s,-NH D ${ }_{2} \mathrm{O}$ exchangeable), $\delta \quad 8.05-8.03$ $(2 \mathrm{H}, \mathrm{d}, J=8 \mathrm{~Hz}$, phthalazine), $\delta$ 7.97-7.95 $(2 \mathrm{H}, \mathrm{d}, J=7.6 \mathrm{~Hz}, \mathrm{Ar}-\mathrm{H}), \delta 7.88-7.86(2 \mathrm{H}, \mathrm{d}$, $J=8 \mathrm{~Hz}$,phthalazine), $\delta 7.63-7.61(2 \mathrm{H}, \mathrm{d}, J=7.6 \mathrm{~Hz}, \mathrm{Ar}-\mathrm{H}), \delta 7.59-7.57(2 \mathrm{H}, \mathrm{d}, J=7.6$ $\mathrm{Hz}, \mathrm{Ar}-\mathrm{H}), \delta$ 7.31-7.28 (2H, m,Ar-H), $\delta 2.91\left(3 \mathrm{H}, \mathrm{s}, \mathrm{CH}_{3}\right)$; FT-IR (v́ max, $\left.\mathrm{cm}^{-}{ }^{1}\right): 3300$, $3192(2 \mathrm{NH}), 1678(\mathrm{C}=\mathrm{O})$; MS (Mwt.: 388.85): m/z $388.90(\mathrm{M}+, 7.10 \%), 279.90$ (7.84\%), 248.95 (25.65\%), 139.00 (100\%); Anal. Calcd for $\mathrm{C}_{22} \mathrm{H}_{17} \mathrm{ClN}_{4} \mathrm{O}: \mathrm{C}, 67.95 ; \mathrm{H}$, 4.41; N, 14.41; Found: C, 68.24; H, 4.48; N, 14.49.

\subsubsection{Synthesis of 1-Aryl-3-(4- (4-substituted phthalazin-1-ylamino)phenyl)ureas (6a-f)}

General procedure:

To a stirred solution of the respective N1-(4-arylphthalazin-1-yl)benzene-1,4diamine (4a,b) $(10.0 \mathrm{mmol}$, 1equiv) in DMF $(20 \mathrm{~mL})$, the respective phenyl isocyanate (viz.; phenyl- isocyanate, 4-chlorophenyl isocyanate, 3-trifluromethyl-4-chlorophenyl isocyanate) (10.0 mmol, lequiv) was added and the mixture was heated under reflux for $6 \mathrm{~h}$, after which TLC $\left(\mathrm{CHCl}_{3} / \mathrm{CH}_{3} \mathrm{OH} 9: 1\right)$ showed no starting material. The reaction mixture was poured over ice- water, the formed precipitate was allowed to settle, then filtered off and dried to afford the crude products(6a-f) which was further crystallized from EtOAc.

\subsubsection{1-Phenyl-3-(4-(phthalazin-1-ylamino)phenyl)urea(6a)}

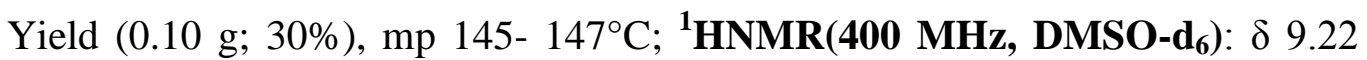
$\left(1 \mathrm{H}, \mathrm{s},-\mathrm{NH} \mathrm{D} \mathrm{D}_{2} \mathrm{O}\right.$ exchangeable), $\delta 9.16\left(1 \mathrm{H}, \mathrm{s},-\mathrm{NH} \mathrm{D}_{2} \mathrm{O}\right.$ exchangeable), $\delta 9.09(1 \mathrm{H}, \mathrm{s},-$ $\mathrm{NH} \mathrm{D}_{2} \mathrm{O}$ exchangeable), $\delta 8.74(1 \mathrm{H}, \mathrm{s}$, phthalazine $), \delta$ 8.68-8.66 $(2 \mathrm{H}, \mathrm{d}, \quad J=8$ Hz,phthalazine), $\delta$ 8.02-8.00 (2H, d, $J=8 \mathrm{~Hz}$, phthalazine), $\delta$ 7.58-7.56 (2H,m,Ar-H), $\delta$ 7.48-7.46 (2H, d, $J=7.6 \mathrm{~Hz}, \mathrm{Ar}-\mathrm{H}), \delta$ 7.31-7.29 (2H,d, $J=7.2 \mathrm{~Hz}, \mathrm{Ar}-\mathrm{H}), \delta$ 7.19-7.17 $(1 \mathrm{H}, \mathrm{m}, \mathrm{Ar}-\mathrm{H}), \delta$ 6.98-6.96 (2H, d, $J=7.2 \mathrm{~Hz}, \mathrm{Ar}-\mathrm{H})$ FT-IR (v́ max, cm- $\left.{ }^{1}\right): 3300,3047$ (3NH), $1700(\mathrm{C}=\mathrm{O})$; MS (Mwt.: 355.14): m/z $355.10(\mathrm{M}+, 8.88 \%), 289.10(9.51 \%)$, 123.10 (15.43\%), 69.00(100.00\%); Anal. Calcd for $\mathrm{C}_{21} \mathrm{H}_{17} \mathrm{~N}_{5} \mathrm{O}: \mathrm{C}, 70.97 ; \mathrm{H}, 4.82$; N, 19.71; Found: C, 71.21; H, 4.89; N, 19.88

\subsubsection{1-(4-Chlorophenyl)-3-(4-(phthalazin-1-ylamino)phenyl)urea (6b)}

Yield (0.20g; 53\%), mp 168-171 ${ }^{\circ} \mathrm{C} ;{ }^{1}$ HNMR(400 MHz, DMSO-d 6 ): $\delta 10.33$ $\left(1 \mathrm{H}, \mathrm{s},-\mathrm{NH} \mathrm{D}_{2} \mathrm{O}\right.$ exchangeable), $\delta 10.07\left(1 \mathrm{H}, \mathrm{s},-\mathrm{NH} \mathrm{D}_{2} \mathrm{O}\right.$ exchangeable), $\delta 9.16(1 \mathrm{H}, \mathrm{s}$, $-\mathrm{NH} \mathrm{D} \mathrm{D}_{2} \mathrm{O}$ exchangeable), $\delta 8.96(1 \mathrm{H}, \mathrm{s}$, phthalazine $), \delta 8.09-8.07(2 \mathrm{H}, \mathrm{d}, J=9.2 \mathrm{~Hz}$, phthalazine), $\delta 7.63-7.61(2 \mathrm{H}, \mathrm{d}, J=9.2 \mathrm{~Hz}$, phthalazine), $\delta 7.49-7.47(2 \mathrm{H}, \mathrm{d}, J=8.8 \mathrm{~Hz}$, Ar-H), $\delta$ 7.44-7.42 (2H,d, J= $8 \mathrm{~Hz}, \mathrm{Ar}-\mathrm{H}), \delta 7.33-7.31$ (d, $J=8.8 \mathrm{~Hz}, 2 \mathrm{H}, \mathrm{Ar}-\mathrm{H}), \delta 6.56-$ $6.54(2 \mathrm{H}, \mathrm{d}, J=8 \mathrm{~Hz}, \mathrm{Ar}-\mathrm{H})$; FT-IR (v́ max, $\left.\mathrm{cm}^{-1}\right)$ : 3396, $3341(3 \mathrm{NH}), 1672(\mathrm{C}=\mathrm{O})$; MS (Mwt.: 389.10): m/z 389.00 (M+, 1.51\%), 281.95 (19.41\%), 253.95(100.00\%), 152.95 (13.00\%); Anal. Calcd for $\mathrm{C}_{21} \mathrm{H}_{16} \mathrm{ClN}_{5} \mathrm{O}$ : C, 64.70; H, 4.14; N, 17.96; Found: C, 64.89; $\mathrm{H}, 4.21 ; \mathrm{N}, 18.17$ 


\subsubsection{1-(4-Chloro-3-(trifluoromethyl)phenyl)-3-(4-(phthalazin-1- ylamino)phenyl)urea (6c)}

Yield (0.22g; 49\%), mp 288-291 ${ }^{\circ} \mathrm{C} ;{ }^{1}$ HNMR(400 MHz, DMSO-d $\left.{ }_{6}\right): \delta 10.08$ $\left(1 \mathrm{H}, \mathrm{s},-\mathrm{NH} \mathrm{D}_{2} \mathrm{O}\right.$ exchangeable $), \delta 9.36\left(1 \mathrm{H}, \mathrm{s},-\mathrm{NH} \mathrm{D}_{2} \mathrm{O}\right.$ exchangeable $), \delta 9.11(1 \mathrm{H}, \mathrm{s},-$ $\mathrm{NH} \mathrm{D}_{2} \mathrm{O}$ exchangeable $), \delta 8.79(1 \mathrm{H}, \mathrm{s}$, phthalazine $), \delta 8.22-8.20(2 \mathrm{H}, \mathrm{d}, J=8.8 \mathrm{~Hz}$, phthalazine), $\delta 8.09(1 \mathrm{H}, \mathrm{s}, \mathrm{Ar}-\mathrm{H}), \delta$ 7.97-7.95 $(1 \mathrm{H}, \mathrm{d}, J=9.6 \mathrm{~Hz}, \mathrm{Ar}-\mathrm{H}), \delta 7.81-7.79$ $(2 \mathrm{H}, \mathrm{d}, J=8.8 \mathrm{~Hz}$, phthalazine), $\delta 7.69-7.67(1 \mathrm{H}, \mathrm{d}, J=9.6 \mathrm{~Hz}, \mathrm{Ar}-\mathrm{H}), \delta 7.59-7.50(2 \mathrm{H}$, $\mathrm{d}, J=8.4 \mathrm{~Hz}, \mathrm{Ar}-\mathrm{H}), \delta$ 7.39-7.37 (2H, d, $J=8.4 \mathrm{~Hz}, \mathrm{Ar}-\mathrm{H})$; FT-IR (v́ max, cm- ${ }^{1}$ ): 3321 , 3263, 3126 (3NH), 1649 (C=O); MS (Mwt.: 457.09): m/z 457.90 (M+, 1.06\%), 415.90 (7.68\%), 194.95(100.00\%); Anal. Calcd for $\mathrm{C}_{22} \mathrm{H}_{15} \mathrm{ClF}_{3} \mathrm{~N}_{5} \mathrm{O}: \mathrm{C}, 57.71 ; \mathrm{H}, 3.30 ; \mathrm{N}$, 15.30; Found: C, 57.93; H, 3.28; N, 15.48

\subsubsection{1-(4-(4-Metyhlphthalazin-1-ylamino)phenyl)3-phenylurea(6d)}

Yield (0.06 g; 20\%), mp 284-286 ${ }^{\circ}$; ${ }^{1}$ HNMR(300 MHz, DMSO-d $)$ : $\delta$ 9.20(1H, s,-NH D $\mathrm{D}_{2} \mathrm{O}$ exchangeable), $\delta 9.14\left(1 \mathrm{H}, \mathrm{s},-\mathrm{NH} \mathrm{D}_{2} \mathrm{O}\right.$ exchangeable), $\delta 9.06(1 \mathrm{H}$, s, $-\mathrm{NH} \mathrm{D}_{2} \mathrm{O}$ exchangeable $), \delta 8.93-8.91(1 \mathrm{H}, \mathrm{d}, J=7 \mathrm{~Hz}$, phthalazine $), \delta 8.77-8.75(1 \mathrm{H}$, $\mathrm{d}, J=7 \mathrm{~Hz}$, phthalazine), $\delta 8.22-8.20(2 \mathrm{H}, \mathrm{d}, J=7 \mathrm{~Hz}$,phthalazine $), \delta 7.85-7.83(2 \mathrm{H}, \mathrm{d}, J=$ $8.4 \mathrm{~Hz}, \mathrm{Ar}-\mathrm{H}), \delta$ 7.52-7.49 (2H, d, $J=8.4 \mathrm{~Hz}, \mathrm{Ar}-\mathrm{H}), \delta$ 7.43-7.40 (2H, d, J= 7.2 Hz,Ar$\mathrm{H}), \delta$ 7.25-7.23 $(1 \mathrm{H}, \mathrm{m}, \mathrm{Ar}-\mathrm{H}), \delta 6.95-6.93(2 \mathrm{H}, \mathrm{d}, J=7.2 \mathrm{~Hz}, \mathrm{Ar}-\mathrm{H}), \delta 2.81(3 \mathrm{H}, \mathrm{s}$, $\mathrm{CH}_{3}$ ); FT-IR (v́ max, $\mathrm{cm}^{-1}$ ): 3292, 3194, $3132(3 \mathrm{NH}), 1651$ (C=O); MS (Mwt.: 369.16): $\mathrm{m} / \mathrm{z} 369.00\left(\mathrm{M}^{+}, 2.99 \%\right), 212.00(6.90 \%), 93.00$ (100.00\%); Anal. Calcd for $\mathrm{C}_{22} \mathrm{H}_{19} \mathrm{~N}_{5} \mathrm{O}$ : C, 71.53; H, 5.18; N, 18.96; Found: C, 71.69; H, 5.27; N, 19.21

\subsubsection{1-(4-Chlorophenyl)-3-(4-(4-methylphthalazin-1-ylamino)phenyl)urea (6e)}

Yield $(0.20 \mathrm{~g} ; 50 \%), \mathrm{mp} 178-180^{\circ} \mathrm{C} ;{ }^{1} \mathbf{H N M R}(400 \mathrm{MHz}$, DMSO-d 6 ): $\delta 9.20(1 \mathrm{H}$, s,-NH D ${ }_{2} \mathrm{O}$ exchangeable), $\delta 9.17\left(1 \mathrm{H}, \mathrm{s},-\mathrm{NH} \mathrm{D}_{2} \mathrm{O}\right.$ exchangeable $), \delta 9.03(1 \mathrm{H}, \mathrm{s},-\mathrm{NH}$ $\mathrm{D}_{2} \mathrm{O}$ exchangeable), $\delta 8.18-8.16(2 \mathrm{H}, \mathrm{d}, J=7.6 \mathrm{~Hz}$, phthalazine), $\delta 8.09-8.05(2 \mathrm{H}, \mathrm{d}, J=$ $7.6 \mathrm{~Hz}$, phthalazine), $\delta$ 7.86-7.84 $(2 \mathrm{H}, \mathrm{d}, J=8.8 \mathrm{~Hz}, \mathrm{Ar}-\mathrm{H}), \delta 7.73-7.71(2 \mathrm{H}, \mathrm{d}, J=8.8$ $\mathrm{Hz}, \mathrm{Ar}-\mathrm{H}), \delta 7.49-7.47(2 \mathrm{H}, \mathrm{d}, J=8.8 \mathrm{~Hz}, \mathrm{Ar}-\mathrm{H}), \delta 7.33-7.30(2 \mathrm{H}, \mathrm{d}, J=8.8 \mathrm{~Hz}, \mathrm{Ar}-\mathrm{H})$, $\delta 2.80\left(3 \mathrm{H}, \mathrm{s}, \mathrm{CH}_{3}\right)$; FT-IR (v́ max, $\left.\mathrm{cm}^{-1}\right): 3294,3188,3168(3 \mathrm{NH}), 1681(\mathrm{C}=\mathrm{O})$; MS (Mwt.: 403.86): m/z 403.00 (M+, 1.51\%), 276.95 (17.01\%), 127.00 (100.00\%); Anal. Calcd for $\mathrm{C}_{22} \mathrm{H}_{18} \mathrm{ClN}_{5} \mathrm{O}$ : C, 65.43; H, 4.49; N, 17.34; Found: C, 65.62; H, 4.52; N, 17.52

\subsubsection{1-(4-Chloro-3-(trifluoromethyl)phenyl)-3-(4-(4-methylphthalazin-1- ylamino)phenyl)urea (6f)}

Yield $\left.(0.30 \mathrm{~g} ; 63 \%), \mathrm{mp} 258-260^{\circ} \mathrm{C} ;{ }^{1} \mathbf{H N M R}(400 \mathrm{MHz}, \text { DMSO-d })_{6}\right): \delta 9.43(1 \mathrm{H}$, s, $-\mathrm{NH} \mathrm{D}_{2} \mathrm{O}$ exchangeable), $\delta 9.14\left(1 \mathrm{H}, \mathrm{s},-\mathrm{NH} \mathrm{D}_{2} \mathrm{O}\right.$ exchangeable), $\delta 9.02(1 \mathrm{H}, \mathrm{s},-\mathrm{NH}$ $\mathrm{D}_{2} \mathrm{O}$ exchangeable), $\delta 8.88-8.86(2 \mathrm{H}, \mathrm{d}, J=8 \mathrm{~Hz}$, phthalazine), $\delta 8.24-8.22(2 \mathrm{H}, \mathrm{d}, J=8$ $\mathrm{Hz}$, phthalazine), $\delta 8.13(1 \mathrm{H}, \mathrm{s}, \mathrm{Ar}-\mathrm{H}), \delta$ 7.97-7.95 $(1 \mathrm{H}, \mathrm{d}, J=9.2 \mathrm{~Hz}, \mathrm{Ar}-\mathrm{H}), \delta$ 7.88-7.86 $(1 \mathrm{H}, \mathrm{d}, J=9.2 \mathrm{~Hz}, \mathrm{Ar}-\mathrm{H}), \delta 7.63-7.61(2 \mathrm{H}, \mathrm{d}, J=10 \mathrm{~Hz}, \mathrm{Ar}-\mathrm{H}), \delta 6.78-6.76(2 \mathrm{H}, \mathrm{d}, J=10$ $\mathrm{Hz}, \mathrm{Ar}-\mathrm{H}), \quad \delta 2.80\left(3 \mathrm{H}, \mathrm{s}, \mathrm{CH}_{3}\right)$; FT-IR (v́ max, $\left.\mathrm{cm}^{-1}\right): 3363,3255,3153(3 \mathrm{NH})$, 1681(C=O); MS (Mwt.: 471.86): m/z 472.10(M+, 0.30\%), 223.00 (43.56\%), 195.00 (70.63\%), 52.05 (100\%); Anal. Calcd for $\mathrm{C}_{23} \mathrm{H}_{17} \mathrm{ClF}_{3} \mathrm{~N}_{5} \mathrm{O}$ : C, 58.54; H, 3.63; N, 14.84; Found: C, 58.61; H, 3.61; N, 15.03

\subsubsection{1-Aryl-3-(4-(4-substituted phthalazin-1-yloxy)phenyl)ureas (7a-f)}

General procedure: 
To a stirred solution of the respective chlorophthalazine derivative $\mathbf{( 3 a , b )}(10.0$ mmol, 1equiv), and caesium carbonate ( $6.5 \mathrm{~g}, 20.0 \mathrm{mmol}$, 2equiv) in acetonitrile (20 $\mathrm{mL})$, the appropriate 1-aryl-3-(4-hydroxyphenyl)urea (1a-c) $(10.0 \mathrm{mmol}$, 1equiv) was added and the mixture was heated under reflux for $6 \mathrm{~h}$, after which TLC $\left(\mathrm{CHCl}_{3} / \mathrm{CH}_{3} \mathrm{OH}\right.$ 9:1) showed no starting material. The filtrate was evaporated in-vacuo to afford the crude product (7a-f) which was further purified by column chromatography (using gradient elution starting from EtOAc then $1 \% \mathrm{MeOH} / \mathrm{EtOAc}$ ).

\subsubsection{1-Phenyl-3-(4-(phthalazin-1-yloxy)phenyl)urea (7a)}

Yield (0.22 g; 64\%), mp 180-182 ${ }^{\circ} \mathrm{C} ;{ }^{1}$ HNMR(300 MHz, DMSO-d 6 ): $\delta 9.57$ $\left(1 \mathrm{H}, \mathrm{s},-\mathrm{NH} \mathrm{D}_{2} \mathrm{O}\right.$ exchangeable $), \delta 9.37\left(1 \mathrm{H}, \mathrm{s},-\mathrm{NH} \mathrm{D}_{2} \mathrm{O}\right.$ exchangeable $), \delta 8.36(1 \mathrm{H}$, s,phthalazine $), \delta 8.10-8.00(2 \mathrm{H}, \mathrm{m}$, phthalazine $), \delta 7.93-7.91(2 \mathrm{H}, \mathrm{d}, J=7 \mathrm{~Hz}$, phthalazine), $\delta$ 7.91-7.90 (2H, m, Ar-H), $\delta$ 7.49-7.47 (2H, d, J=7.8 Hz, Ar-H), $\delta$ 7.19$7.25(\mathrm{~m}, 3 \mathrm{H}, \mathrm{Ar}-\mathrm{H}), \delta 6.89-6.86(1 \mathrm{H}, \mathrm{d}, J=7.5 \mathrm{~Hz}, \mathrm{Ar}-\mathrm{H}), \delta 6.67-6.65(2 \mathrm{H}, \mathrm{d}, J=7.8$ Hz,Ar-H); FT-IR (v́ max, $\left.\mathrm{cm}^{-1}\right)$ : 3304, 3235 (2NH), $1641(\mathrm{C}=\mathrm{O})$; MS (Mwt.: 356.38): m/z $355.00\left(\mathrm{M}-1^{+}, 0.11 \%\right), 146.05$ (23.71\%), 118.05 (8.47\%), 79.95 (100.00\%);Anal. Calcd for $\mathrm{C}_{21} \mathrm{H}_{16} \mathrm{~N}_{4} \mathrm{O}_{2}$ : C, 70.77; H, 4.53; N, 15.72; Found: C,71.02; H, 4.61; N, 15.89

\subsubsection{1-(4-Chlorophenyl)-3-(4-(phthalazin-1-yloxy)phenyl)urea (7b)} $(1 \mathrm{H}, \mathrm{s}$,

Yield (0.19 g; 50\%), mp 166-168 ${ }^{\circ}$; ${ }^{1}$ HNMR(400 MHz, DMSO-d 6 ): $\delta 9.72$

- $\mathrm{NH} \mathrm{D}_{2} \mathrm{O}$ exchangeable), $\delta 9.44\left(1 \mathrm{H}, \mathrm{s},-\mathrm{NH} \mathrm{D}_{2} \mathrm{O}\right.$ exchangeable $), \delta 8.37(1 \mathrm{H}, \mathrm{s}$, phthalazine), $\delta 8.28-8.26(2 \mathrm{H}, \mathrm{d}, J=8 \mathrm{~Hz}$, phthalazine), $\delta 8.18-8.16(2 \mathrm{H}, \mathrm{d}, J=8 \mathrm{~Hz}$, phthalazine), $\delta 7.58-7.56(2 \mathrm{H}, \mathrm{d}, J=8.8 \mathrm{~Hz}, \mathrm{Ar}-\mathrm{H}), \delta 7.56-7.53(2 \mathrm{H}, \mathrm{d}, J=8.8 \mathrm{~Hz}, \mathrm{Ar}-$ $\mathrm{H}), \delta$ 7.36-7.34 $(2 \mathrm{H}, \mathrm{d}, J=7.2 \mathrm{~Hz}, \mathrm{Ar}-\mathrm{H}), \delta 7.14-7.12(2 \mathrm{H}, \mathrm{d}, J=7.2 \mathrm{~Hz}$, Ar-H); FT-IR (v́ $\left.\max , \mathrm{cm}^{-1}\right): 3278,3161(2 \mathrm{NH}), 1701(\mathrm{C}=\mathrm{O})$; MS (Mwt.: 390.82): $\mathrm{m} / \mathrm{z} 390.10$ (4.47\%), 365.10 (24.02\%), 75.00 (100.00\%);Anal. Calcd for $\mathrm{C}_{21} \mathrm{H}_{15} \mathrm{ClN}_{4} \mathrm{O}_{2}$ : C, 64.54; H, 3.87; N, 14.34; Found: C, 64.69; H, 4.01; N, 14.62

\subsubsection{1-(4-Chloro-3-(trifluoromethyl)phenyl)-3-(4-(phthalazin-1- yloxy)phenyl)urea (7c)}

Yield $(0.22 \mathrm{~g} ; 49 \%)$, mp $158-160^{\circ} \mathrm{C} ;{ }^{1}$ HNMR(400 MHz, DMSO-d $)$ ): $\delta 9.91$ $\left(1 \mathrm{H}, \mathrm{s},-\mathrm{NH} \mathrm{D}_{2} \mathrm{O}\right.$ exchangeable), $\delta 9.08\left(\mathrm{~s}, 1 \mathrm{H},-\mathrm{NH} \mathrm{D}_{2} \mathrm{O}\right.$ exchangeable), $\delta 8.39(\mathrm{~s}, 1 \mathrm{H}$, phthalazine), $\delta 8.24-8.21$ (d, $J=8 \mathrm{~Hz}, 2 \mathrm{H}$, phthalazine), $\delta 8.17-8.15(\mathrm{~d}, J=8 \mathrm{~Hz}, 2 \mathrm{H}$, phthalazine), $\delta 7.99$ (s, $1 \mathrm{H}, \mathrm{Ar}-\mathrm{H}), \delta 7.85-7.83(\mathrm{~d}, J=7.6 \mathrm{~Hz}, 1 \mathrm{H}, \mathrm{Ar}-\mathrm{H}), \delta 7.76-7.74(\mathrm{~d}$, $J=7.6 \mathrm{~Hz}, 1 \mathrm{H}, \mathrm{Ar}-\mathrm{H}), \delta 7.28-7.26(\mathrm{~d}, J=8.4 \mathrm{~Hz}, 2 \mathrm{H}, \mathrm{Ar}-\mathrm{H}), \delta 6.76-6.74(\mathrm{~d}, J=8.4 \mathrm{~Hz}$, 1H, Ar-H); FT-IR (v́ max, $\mathrm{cm}^{-1}$ ): 3300, $3153(2 \mathrm{NH}), 1679$ (C=O); MS (Mwt.: 458.82): $\mathrm{m} / \mathrm{z} \quad 458.10 \quad(2.63 \%), 271.05 \quad(7.73 \%), \quad 195.00 \quad(100.00 \%)$; Anal. Calcd for $\mathrm{C}_{22} \mathrm{H}_{14} \mathrm{ClF}_{3} \mathrm{~N}_{4} \mathrm{O}_{2}$ : C, 57.59; H, 3.08; N, 12.21; Found: C, 57.82; H, 3.06; N, 12.57

\subsubsection{1-(4-(4-Methylphthalazin-1-yloxy)-3-phenyl)urea (7d)}

Yield (0.20 g; 54\%), mp 174-176 ${ }^{\circ} \mathrm{C} ;{ }^{1} \mathbf{H N M R ( 4 0 0 ~ M H z , ~ D M S O - d _ { 6 } ) :} \delta 9.44$ $\left(2 \mathrm{H}, \mathrm{s},-\mathrm{NH} \mathrm{D}_{2} \mathrm{O}\right.$ exchangeable), $\delta 8.38-8.36(1 \mathrm{H}, \mathrm{d}, J=8 \mathrm{~Hz}$, phthalazine $), \delta 8.31-8.29$ $(1 \mathrm{H}, \mathrm{d}, J=8 \mathrm{~Hz}$, phthalazine), $\delta 8.29-8.27(1 \mathrm{H}, \mathrm{d}, J=8 \mathrm{~Hz}$, phthalazine), $\delta 8.19-8.17$ $(1 \mathrm{H}, \mathrm{d}, J=8 \mathrm{~Hz}$, phthalazine), $\delta 7.59-7.57(1 \mathrm{H}, \mathrm{d}, J=8.8 \mathrm{~Hz}, \mathrm{Ar}-\mathrm{H}), \delta 7.52-7.50(1 \mathrm{H}, \mathrm{d}$, $J=8.8 \mathrm{~Hz}, \mathrm{Ar}-\mathrm{H}), \delta$ 7.46-7.44 (2H, m,Ar-H), $\delta .28-7.26(2 \mathrm{H}, \mathrm{d}, J=7.6 \mathrm{~Hz}, \mathrm{Ar}-\mathrm{H}), \delta$ 6.96-6.91 $(1 \mathrm{H}, \mathrm{d}, J=8.8 \mathrm{~Hz}, \mathrm{Ar}-\mathrm{H}), \delta 6.67-6.65(2 \mathrm{H}, \mathrm{d}, J=7.6 \mathrm{~Hz}, \mathrm{Ar}-\mathrm{H}), \delta 2.81(3 \mathrm{H}$, s, $\mathrm{CH}_{3}$ ); FT-IR (v́ max, $\mathrm{cm}^{-}{ }^{1}$ ): 3302, $3141(2 \mathrm{NH}), 1643(\mathrm{C}=\mathrm{O})$; MS (Mwt.: 370.40): m/z 
370.00[M $\mathrm{M}^{+}, 2.28 \%$ ), 277.95 (19.33\%), 251.00 (100.00\%);Anal. Calcd for $\mathrm{C}_{22} \mathrm{H}_{18} \mathrm{~N}_{4} \mathrm{O}_{2}$ : C, 71.34; H, 4.90; N, 15.13; Found: C, 71.49; H, 4.97; N, 15.29.

\subsubsection{1-(4-Chlorophenyl)-3-(4-(4-methylphthalazin-1-yloxy)phenyl)urea (7e)}

Yield (0.17 g; 42\%), mp 169-171 ${ }^{\circ} \mathrm{C} ;{ }^{1} \mathbf{H N M R ( 4 0 0 ~ M H z , ~ D M S O - d _ { 6 } ) : ~} \delta 10.06$ $\left(1 \mathrm{H}, \mathrm{s},-\mathrm{NH} \mathrm{D}_{2} \mathrm{O}\right.$ exchangeable), $\delta 10.05\left(1 \mathrm{H}, \mathrm{s},-\mathrm{NH} \mathrm{D}_{2} \mathrm{O}\right.$ exchangeable), $\delta 8.38-8.36$ $(1 \mathrm{H}, \mathrm{d}, J=7.6 \mathrm{~Hz}$, phthalazine), $\delta 8.20-8.18(1 \mathrm{H}, \mathrm{d}, J=7.6 \mathrm{~Hz}$,phthalazine), $\delta 8.07-8.04$ $(2 \mathrm{H}, \mathrm{d}, J=7.6 \mathrm{~Hz}$, phthalazine), $\delta 7.58-7.56(2 \mathrm{H}, \mathrm{d}, J=8.4 \mathrm{~Hz}, \mathrm{Ar}-\mathrm{H}), \delta 7.29-7.22(2 \mathrm{H}$, $\mathrm{d}, J=8.4 \mathrm{~Hz}, \mathrm{Ar}-\mathrm{H}), \delta 7.20-7.18(2 \mathrm{H}, \mathrm{d}, J=9.2 \mathrm{~Hz}, \mathrm{Ar}-\mathrm{H}), \delta 6.66-6.63(2 \mathrm{H}, \mathrm{d}, J=9.2$ $\mathrm{Hz}, \mathrm{Ar}-\mathrm{H}), \delta 2.81\left(3 \mathrm{H}, \mathrm{s}, \mathrm{CH}_{3}\right)$; FT-IR (v́ max, $\left.\mathrm{cm}^{-}{ }^{1}\right): 3300,3153(2 \mathrm{NH}), 1643(\mathrm{C}=\mathrm{O})$; MS (Mwt.: 404.85): m/z 404.90(M+, 2.04\%), 385.85 (1.29\%), 267.90 (4.75), 250.95 (28.16), 127.00 (100.00\%); Anal. Calcd for $\mathrm{C}_{22} \mathrm{H}_{17} \mathrm{ClN}_{4} \mathrm{O}_{2}: \mathrm{C}, 65.27 ; \mathrm{H}, 4.23 ; \mathrm{N}, 13.84$; Found: C, 65.52; H, 4.28; N, 13.97

\subsubsection{1-(4-Chloro-3-(trifluoromethyl)phenyl)-3-(4-(4-metyhlphthalazin-1- yloxy)phenyl)urea (7f)}

Yield (0.20 g; 42\%), mp 150-152 ${ }^{\circ} \mathrm{C} ;{ }^{1} \mathbf{H}$ NMR(400 MHz, DMSO-d $\left.{ }_{6}\right): \delta 10.31$ $\left(1 \mathrm{H}, \mathrm{s},-\mathrm{NH} \mathrm{D} \mathrm{D}_{2} \mathrm{O}\right.$ exchangeable), $\delta 10.27\left(1 \mathrm{H}, \mathrm{s},-\mathrm{NH} \mathrm{D}_{2} \mathrm{O}\right.$ exchangeable), $\delta 8.37(1 \mathrm{H}$, s, Ar-H), $\delta 8.19-8.16(2 \mathrm{H}, \mathrm{d}, J=8 \mathrm{~Hz}$, phthalazine), $\delta 8.07-8.05(1 \mathrm{H}, \mathrm{d}, J=7.6 \mathrm{~Hz}, \mathrm{Ar}-$ $\mathrm{H}), \delta$ 7.78-8.75 (2H,d, $J=8 \mathrm{~Hz}$, phthalazine), $\delta 7.61-7.59(1 \mathrm{H}, \mathrm{d}, J=7.6 \mathrm{~Hz}, \mathrm{Ar}-\mathrm{H}), \delta$ 7.56-7.54 (2H, d, $J=8.8 \mathrm{~Hz}, \mathrm{Ar}-\mathrm{H}), \delta 7.24-7.19(2 \mathrm{H}, \mathrm{d}, J=8.8 \mathrm{~Hz}, \mathrm{Ar}-\mathrm{H}), \delta 2.80(3 \mathrm{H}$, s, $\left.\mathrm{CH}_{3}\right)$; FT-IR (v́ max, $\mathrm{cm}^{-}{ }^{1}$ ): 3300, $3153(2 \mathrm{NH}), 1679(\mathrm{C}=\mathrm{O})$; MS (Mwt.: 472.85): m/z 472.80 (M+, 2.07\%), 391.95 (10.86), 335.85 (25.53), 250.95 (86.76\%), 194.90 (100\%); Anal. Calcd for $\mathrm{C}_{23} \mathrm{H}_{16} \mathrm{ClF}_{3} \mathrm{~N}_{4} \mathrm{O}_{2}$ : C, 58.42; H, 3.41; N, 11.85; Found: C, 58.49; H, 3.39; $\mathrm{N}, 12.01$

\subsubsection{Synthesis of Ethyl 4-(4-substituted phthalazine-1-yl)piperazine-1-carboxylate \&}

\section{1-Aryl-4-(arylpiperazine-1-yl)phthalazine (8a-j)}

General procedure:

To a stirred mixture of the respective 1-chlorophthalazine (3a,b) $(10.0 \mathrm{mmol}$, 1equiv), potassium carbonate $(0.27 \mathrm{~g}, 20.0 \mathrm{mmol}$, 2equiv $)$, potassium iodide $(0.01 \mathrm{~g}, 0.01$ mmol, 0.1equiv) in absolute ethanol $(20 \mathrm{~mL})$, the respective piperazine (viz.; ethylpiperazinecarboxylate , phenylpiperazine, 2-flourophenylpiperazine, 2pyridylpiperazine, 2-furoylpiperazine) (10.0 mmol, 1equiv) was added and the mixture was heated under reflux for $2 \mathrm{~h}$, after which TLC $\left(\mathrm{CHCl}_{3} / \mathrm{CH}_{3} \mathrm{OH}\right.$ 9:1) showed no starting material. The mixture was then concentrated in vacuo, the residue was washed with water, extracted with EtOAc, dried over anhydrous $\mathrm{Na}_{2} \mathrm{SO}_{4}$. The crude product was recrystallized from EtOAc. 


\subsubsection{Ethyl 4-(phthalazin-1-yl)piperazine-1-carboxylate (8a)}

Yield (0.19 g; 68\%), mp 271-273 ${ }^{\circ} \mathrm{C} ;{ }^{1} \mathbf{H N M R ( 3 0 0 ~ M H z , ~ D M S O ) : ~} \delta 8.10(1 \mathrm{H}$, s, phthalazine), $\delta 7.98-7.96(2 \mathrm{H}, \mathrm{d}, J=7 \mathrm{~Hz}$, phthalazine), $\delta 7.93-7.91(2 \mathrm{H}, \mathrm{d}, J=7 \mathrm{~Hz}$, phthalazine), $\delta 4.07$ (2H, q, $\left.\underline{\mathrm{CH}}_{2}-\mathrm{CH}_{3}\right), \delta 3.63-3.62$ (2H, m, piperazine ring), $\delta 2.86-2.85$ $(2 \mathrm{H}, \mathrm{m}$,piperazine ring $), \delta 2.55-2.54(2 \mathrm{H}, \mathrm{m}$, piperazine ring $), \delta 2.27-2.26(2 \mathrm{H}, \mathrm{m}$, piperazine ring), $\delta 1.14\left(3 \mathrm{H}, \mathrm{t}, \mathrm{CH}_{2}-\mathrm{CH}_{3}\right)$, FT-IR (v́ max, $\left.\mathrm{cm}^{-}{ }^{1}\right): 1672(\mathrm{C}=\mathrm{O})$; MS (Mwt.: 286.33): m/z 286.05 ( $\left.\mathrm{M}^{+}, 0.95 \%\right), 270.00$ (3.77\%), 56.00 (100.00\%);Anal. Calcd for $\mathrm{C}_{15} \mathrm{H}_{18} \mathrm{~N}_{4} \mathrm{O}_{2}$ : C, 62.92; H, 6.34; N, 19.57; Found: C, 63.23; H, 6.38; N, 19.71

\subsubsection{1-(4-Phenylpiperazin-1-yl)phthalazine ( $8 b)$}

Yield (0.20g; 69\%), mp 242-244 ${ }^{\circ} \mathrm{C} ;{ }^{1}$ HNMR(300 MHz, DMSO): $\delta 8.15-8.13$ (3H, m, phthalazine), $\delta 7.98-7.96(2 \mathrm{H}, \mathrm{d}, J=7.5 \mathrm{~Hz}$,phthalazine), $\delta$ 7.27-7.24 (1H, m,Ar$\mathrm{H}), \delta$ 6.98-6.95 (2H, m,Ar-H), $\delta 6.86-6.84(2 \mathrm{H}, \mathrm{d}, J=7.2 \mathrm{~Hz}, \mathrm{Ar}-\mathrm{H}), \delta 3.57-3.56(2 \mathrm{H}$, m,piperazine ring $), \delta 3.43-3.42(2 \mathrm{H}, \mathrm{m}$, piperazine ring $), \delta 3.33-3.32(2 \mathrm{H}, \mathrm{m}$, piperazine ring), $\delta 3.12-3.11\left(2 \mathrm{H}, \mathrm{m}\right.$,piperazine ring), FT-IR (v́ $\left.\max , \mathrm{cm}^{-1}\right): 3428$ (CH aromatic), 2991, 2919 (CH aliphatic); MS (Mwt.: 290.36): m/z 290.10 ( $\left.\mathbf{M}^{+}, 0.41 \%\right), 162.10$ (8.10\%), 120.10 (100.00\%), Anal. Calcd for $\mathrm{C}_{18} \mathrm{H}_{18} \mathrm{~N}_{4}$ : C, 74.46; H, 6.25; N, 19.30; Found: C, 74.62; H, 6.37; N, 19.54 .

\subsubsection{1-(4-(2-Fluorophenyl)piperazin-1-yl)phthalazine $(8 c)$}

Yield $(0.21 \mathrm{~g} ; 70 \%), \mathrm{mp} 88-90^{\circ} \mathrm{C} ;{ }^{1} \mathbf{H N M R}(300 \mathrm{MHz}$, DMSO): $\delta 8.61(1 \mathrm{H}$, s,phthalazine), $\delta 8.27-8.24(2 \mathrm{H}, \mathrm{d}, J=9 \mathrm{~Hz}$, phthalazine), $\delta 8.14-8.11(2 \mathrm{H}, \mathrm{d}, J=9 \mathrm{~Hz}$, phthalazine), $\delta$ 7.19-7.17 $(1 \mathrm{H}, \mathrm{d}, J=7.6 \mathrm{~Hz}, \mathrm{Ar}-\mathrm{H}), \delta 7.15-7.13(1 \mathrm{H}, \mathrm{d}, J=7.6 \mathrm{~Hz}, \mathrm{Ar}-$ $\mathrm{H}), \delta$ 7.08-7.06 (1H, d,J= 7.6 Hz, Ar-H), $\delta 6.99-6.97(1 \mathrm{H}, \mathrm{d}, J=7.6 \mathrm{~Hz}, \mathrm{Ar}-\mathrm{H}), \delta 3.70-$ $3.69(2 \mathrm{H}$, m,piperazine ring), $\delta 3.31-3.30(2 \mathrm{H}, \mathrm{m}$,piperazine ring), $\delta 3.23-3.21(4 \mathrm{H}$, m,piperazine ring); FT-IR (v́ max, $\mathrm{cm}^{-1}$ ): 3039 ( $\mathrm{CH}$ aromatic), 2924 (CH aliphatic); $\begin{array}{llllllll}\text { MS (Mwt.: 308.35): } & \mathrm{m} / \mathbf{z} & 308.05 & \left(\mathrm{M}^{+},\right. & 1.81 \%), & 180.05 & (19.88 \%), & 138.10\end{array}$ (100.00\%);Anal. Calcd for $\mathrm{C}_{18} \mathrm{H}_{17} \mathrm{FN}_{4}$ : C, 70.11; H, 5.56; N, 18.17; Found: C, 70.29; H, $5.60 ; \mathrm{N}, 18.28$.

\subsubsection{1-(4-(Pyridin-2-yl)piperazin-1-yl)phthalazine (8d)}

Yield (0.20g; 69\%), mp 286-288 ${ }^{\circ}$; ${ }^{1}$ HNMR(300 MHz, DMSO): $\delta$ 8.14-8.12 (1H, d, $J=7 \mathrm{~Hz}$,pyridine ring), $\delta 7.93-7.91(3 \mathrm{H}, \mathrm{m}$, phthalazine), $\delta 7.59-7.56(2 \mathrm{H}, \mathrm{d}, J=$ $9 \mathrm{~Hz}$, phthalazine), $\delta 7.56-7.54(1 \mathrm{H}, \mathrm{d}, J=7 \mathrm{~Hz}$,pyridine ring), $\delta 6.69-6.67(2 \mathrm{H}, \mathrm{d}, J=$ $7 \mathrm{~Hz}$,pyridine ring), $\delta 3.67-3.65$ (4H, m,piperazine ring), $\delta 3.06-3.04(4 \mathrm{H}$, m,piperazine ring); FT-IR (v́ $\left.\max , \mathrm{cm}^{-1}\right): 3030$ (CH aromatic), 2926 (CH aliphatic); MS (Mwt.: 291.35): m/z 291.10(M+, 0.19\%), 279.05 (0.28\%), 160.10 (27.24\%), 95.05 (100.00); Anal. Calcd for $\mathrm{C}_{17} \mathrm{H}_{17} \mathrm{~N}_{5}$ : C, 70.08; H, 5.88; N, 24.04; Found: C, 70.32; H, 5.64; N, 24.31

\subsubsection{5. furan-2-yl(4-(phthalazin-1-yl)piperazin-1-yl)methanone (8e)}

Yield (0.23g; 77\%), mp 90-92 ${ }^{\circ} \mathrm{C} ;{ }^{1}$ HNMR(300 MHz, DMSO): $\delta 8.36(1 \mathrm{H}, \mathrm{s}$, phthalazine), $\delta 8.12-8.10(1 \mathrm{H}, \mathrm{d}, J=7 \mathrm{~Hz}$, furoyl $\mathrm{ring}), \delta 8.03-8.01(2 \mathrm{H}, \mathrm{d}, J=7.8 \mathrm{~Hz}$, phthalazine), $\delta 7.98-7.96(2 \mathrm{H}, \mathrm{d}, J=7.8 \mathrm{~Hz}$, phthalazine), $\delta 6.99-6.98(2 \mathrm{H}, \mathrm{d}, J=7 \mathrm{~Hz}$, furoylring), $\delta 3.69-3.67(4 \mathrm{H}$, m,piperazine ring), $\delta 2.91-2.90(4 \mathrm{H}, \mathrm{m}$, piperazine ring); FT-IR (v́ max, $\left.\mathrm{cm}^{-1}\right)$ : $1679(\mathrm{C}=\mathrm{O})$; MS (Mwt.: 308.33): $\mathrm{m} / \mathrm{z} 308.05(\mathrm{M}+, 4.64 \%)$, $274.00(6.66 \%), 158.05(57.70 \%), 95.00$ (100.00\%) Anal. Calcd for $\mathrm{C}_{17} \mathrm{H}_{16} \mathrm{~N}_{4} \mathrm{O}_{2}: \mathrm{C}$, 66.22; H, 5.23; N, 18.17; Found: C, 66.41; H, 5.32; N, 18.40 


\subsubsection{Ethyl 4-(4-methylphthalazin-1-yl)piperazine-1-carboxylate (8f)}

Yield (0.22 g; 73\%), mp 95-97 $\left.{ }^{\circ} \mathrm{C} ;{ }^{1} \mathbf{H N M R ( 3 0 0 ~} \mathbf{M H z}, \mathbf{C D C l}_{3}\right): \delta$ 8.43-8.41 (2H, d, $J=8.1 \mathrm{~Hz}$,phthalazine), $\delta 8.36-8.34(2 \mathrm{H}, \mathrm{d}, J=8.1 \mathrm{~Hz}$, phthalazine), $\delta 4.19(2 \mathrm{H}$, $\left.\mathrm{q}, \underline{\mathrm{CH}}_{2}-\mathrm{CH}_{3}\right), \delta 3.75-3.74$ (2H, m,piperazine ring), $\delta$ 3.65-3.64 (2H, m,piperazine ring), $\delta$ 3.37-3.36 (2H, m,piperazine ring), $\delta 3.18-3.17(2 \mathrm{H}, \mathrm{m}$, piperazine ring), $\delta 2.58(3 \mathrm{H}, \mathrm{s}$, $\left.\mathrm{CH}_{3}\right), \delta 1.33\left(3 \mathrm{H}, \mathrm{t}, \mathrm{CH}_{3}-\mathrm{CH}_{2}\right)$; FT-IR (v́ max, $\left.\mathrm{cm}^{-}{ }^{1}\right): 1693(\mathrm{C}=\mathrm{O})$; MS (Mwt.: 300.36): $\mathrm{m} / \mathrm{z}$ 300.05(M+, 5.71\%), 244.05 (3.15\%), 184.55 (13.85\%), 172.30 (48.47\%), 55.65 $(100 \%)$; Anal. Calcd for $\mathrm{C}_{16} \mathrm{H}_{20} \mathrm{~N}_{4} \mathrm{O}_{2}$ : C, 63.98; H, 6.71; N, 18.65; Found: C, 64.17; H, $6.83 ; \mathrm{N}, 19.01$

\subsubsection{1-Methyl-4-(4-phenylpiperazin-1-yl)phthalazine (8g)}

Yield $(0.15 \mathrm{~g} ; \quad 56 \%), \mathrm{mp} 229-231^{\circ} \mathrm{C} ;{ }^{1}$ HNMR(300 MHz, DMSO): $\delta$ 7.28$7.26(2 \mathrm{H}, \mathrm{d}, J=7.2 \mathrm{~Hz}$, phthalazine), $\delta 7.25-7.23(2 \mathrm{H}, \mathrm{d}, J=7.2 \mathrm{~Hz}$, phthalazine), $\delta 6.99-$ $6.97(2 \mathrm{H}, \mathrm{d}, J=7.8 \mathrm{~Hz}, \mathrm{Ar}-\mathrm{H}), \delta 6.88-6.86(1 \mathrm{H}, \mathrm{m}, \mathrm{Ar}-\mathrm{H}), \delta 6.85-6.83(2 \mathrm{H}, \mathrm{d}, J=7.8$ $\mathrm{Hz}, \mathrm{Ar}-\mathrm{H}), \delta 3.34-3.32$ (4H, m, piperazine ring), $\delta 3.22-3.20$ (4H, m,piperazine ring), $\delta$ $2.48\left(3 \mathrm{H}, \mathrm{s}, \mathrm{CH}_{3}\right)$; FT-IR (v́ max, $\left.\mathrm{cm}^{-1}\right): 3070$ ( $\mathrm{CH}$ aromatic), 2954 ( $\mathrm{CH}$ aliphatic); MS (Mwt.: 304.39): m/z 304.00(M+, 1.73\%), 284.60 (2.19\%), 192.35 (5.24\%), 105.20 (34.33\%), $55.65(100.00 \%)$; Anal. Calcd for $\mathrm{C}_{19} \mathrm{H}_{20} \mathrm{~N}_{4}$ : C, 74.97; H, 6.62; N, 18.41; Found: C, 80.32; H, 6.70; N, 18.48 .

\subsubsection{1-(4-(2-fluorophenyl)piperazin-1-yl)-4-methylphthalazine (8h)}

Yield (0.12 g; 71\%), mp 149-151 $\left.{ }^{\circ} \mathrm{C} ;{ }^{1} \mathbf{H N M R ( 3 0 0 ~} \mathbf{M H z}, \mathbf{C D C l}_{3}\right): \delta 8.15-8.13$ $(1 \mathrm{H}, \mathrm{d}, J=9.6 \mathrm{~Hz}$, phthalazine), $\delta \quad 8.05-8.01(1 \mathrm{H}, \mathrm{d}, J=9.6 \mathrm{~Hz}$, phthalazine), $\delta$ 7.87$7.83(2 \mathrm{H}, \mathrm{d}, J=9.6 \mathrm{~Hz}$, phthalazine), $\delta$ 7.07-7.04 $(2 \mathrm{H}, \mathrm{d}, J=8.7 \mathrm{~Hz}, \mathrm{Ar}-\mathrm{H}), \delta 6.99-6.97$ $(2 \mathrm{H}, \mathrm{d}, \mathrm{Ar}-\mathrm{H}), \delta 3.69-3.67$ (4H, m,piperazine ring), $\delta 3.48-3.46(4 \mathrm{H}, \mathrm{m}$, piperazine ring), $\delta 2.03\left(3 \mathrm{H}, \mathrm{s}, \mathrm{CH}_{3}\right)$; FT-IR (v́ max, $\left.\mathrm{cm}^{-1}\right): 3035$ ( $\mathrm{CH}$ aromatic), 2951 ( $\mathrm{CH}$ aliphatic); MS (Mwt.: 322.38): m/z $323.50[\mathrm{M}+1 \mathrm{H}]^{+}$(9.74\%), $172.15 \quad(48.77 \%),$, (100.00\%); Anal. Calcd for $\mathrm{C}_{19} \mathrm{H}_{19} \mathrm{FN}_{4}$ : C, 70.79; H, 5.94; N, 17.38; Found: C, 71.03; $\mathrm{H}, 5.99 ; \mathrm{N}, 18.48$.

\subsubsection{1-Methyl-4-(4-(pyridin-2-yl)piperazin-1-yl)phthalazine (8i)}

Yield $(0.10 \mathrm{~g} ; 59 \%)$, mp 226-228 ${ }^{\circ} \mathrm{C}$; ${ }^{1}$ HNMR(300 MHz, DMSO): $\delta$ 8.16$8.13(1 \mathrm{H}, \mathrm{d}, J=8.7 \mathrm{~Hz}$,pyridyl ring), $\delta 7.62-7.60(2 \mathrm{H}, \mathrm{d}, J=8.4 \mathrm{~Hz}$, phthalazine), $\delta 7.58$ $7.56(2 \mathrm{H}, \mathrm{d}, J=8.4 \mathrm{~Hz}$, phthalazine), $\delta \quad 6.91-6.89(1 \mathrm{H}, \mathrm{d}, J=8.7 \mathrm{~Hz}$, pyridyl ring), $\delta$ 6.74-6.72 (2H, d, $J=8.7 \mathrm{~Hz}$, pyridyl ring), $\delta 3.75-3.73(4 \mathrm{H}, \mathrm{m}$, piperazine ring), $\delta 3.12-$ $3.10\left(4 \mathrm{H}, \mathrm{m}\right.$,piperazine ring), $\delta 2.08\left(3 \mathrm{H}, \mathrm{s}, \mathrm{CH}_{3}\right)$; FT-IR (v́ $\left.\max , \mathrm{cm}^{-1}\right) 3132(\mathrm{CH}$ aromatic), 2954 (CH aliphatic); MS (Mwt.: 305.38): m/z 305.15 (M+, 1.16\%), 185.65 (16.50\%), $172.35(41.23 \%),, 55.55(100.00 \%)$; Anal. Calcd for $\mathrm{C}_{18} \mathrm{H}_{19} \mathrm{~N}_{5}: \mathrm{C}, 70.80 ; \mathrm{H}$, 6.27; N, 22.93; Found: C, 71.04; H, 6.38; N, 23.18.

\subsubsection{Furan-2-yl(4-(4-methylphthalazin-1-yl)piperazin-1-yl)methanone (8j)}

Yield (0.11g; 60\%), mp 90-92 ${ }^{\circ} \mathrm{C} ;{ }^{1} \mathbf{H N M R ( 3 0 0 ~ M H z , ~ D M S O ) : ~} \delta$ 8.32-8.30 (2H, $\mathrm{d}, J=7 \mathrm{~Hz}$, phthalazine), $\delta 8.29-8.27(2 \mathrm{H}, \mathrm{d}, J=7 \mathrm{~Hz}$, phthalazine $), \delta 7.82-7.81(1 \mathrm{H}, \mathrm{d}$, $J=7.2 \mathrm{~Hz}$, furoyl ring), $\delta 6.97-6.96(1 \mathrm{H}, \mathrm{d}, J=7.2 \mathrm{~Hz}$, furoyl ring), $\delta 6.62-6.60(1 \mathrm{H}, \mathrm{t}$, $J=7.2 \mathrm{~Hz}$, furoyl- $\mathrm{H}), \delta 3.64-3.62(4 \mathrm{H}, \mathrm{m}$, piperazine ring), $\delta 3.41-3.39(4 \mathrm{H}$, m,piperazine ring), $\delta 2.48\left(3 \mathrm{H}, \mathrm{s}_{2} \mathrm{CH}_{3}\right)$; FT-IR (v́ max, $\left.\mathrm{cm}^{-}{ }^{1}\right): 1610(\mathrm{C}=\mathrm{O})$; MS (Mwt.: 322.36): m/z 322.00 (M+, 6.60\%), 184.00 (31.70\%), 172.00 (100.00\%); Anal. Calcd for $\mathrm{C}_{18} \mathrm{H}_{18} \mathrm{~N}_{4} \mathrm{O}_{2}$ : C, 67.07; H, 5.63; N, 17.38; Found: C, 67.21; H, 5.69; N, 17.52 


\subsection{Biological Evaluation}

\subsubsection{Evaluation for cytotoxic activity against NCI 60 human cancer cell lines panel.}

\subsubsection{Assay protocol}

The human tumor cell lines of the cancer-screening panel were grown in RPMI 1640 medium containing 5\% fetal bovine serum and $2 \mu \mathrm{M}$ L-glutamine. For a typical screening experiment, cells are inoculated into 96 well microtiter plates in $100 \mathrm{ml}$ at plating densities ranging from 5000 to 40,000 cells/well depending on the doubling time of individual cell lines. After cell inoculation, the microtiter plates are incubated at 37 ${ }^{\circ} \mathrm{C}, 5 \% \mathrm{CO}_{2}, 95 \%$ air and $100 \%$

relative humidity for $24 \mathrm{~h}$ prior to addition of experimental drugs. After $24 \mathrm{~h}$, two plates of each cell line are fixed in situ with TCA, to represent a measurement of the cell population for each cell line at the time of drug addition $(\mathrm{Tz})$. Experimental drugs are solubilized in dimethyl sulfoxide at 400-fold the desired final maximum test concentration and stored frozen prior to use. At the time of drug addition, an aliquot of frozen concentrate is thawed and diluted to twice the desired final maximum test concentration with complete medium containing $50 \mathrm{mg} / \mathrm{ml}$ Gentamicin. Additional four, 10 -fold or $1 / 2 \log$ serial dilutions are made to provide a total of five drug concentrations plus control. Aliquots of $100 \mathrm{ml}$ of these different drug dilutions are added to the appropriate microtiter wells already containing $100 \mathrm{ml}$ of medium, resulting in the required final drug concentrations. Following drug addition, the plates are incubated for an additional $48 \mathrm{~h}$ at $37{ }^{\circ} \mathrm{C}, 5 \% \mathrm{CO}_{2}, 95 \%$ air, and $100 \%$ relative humidity. For adherent cells, the assay is terminated by the addition of cold TCA. Cells are fixed in situ by the gentle addition of $50 \mathrm{ml}$ of cold $50 \%$ (w/v) TCA (final concentration, $10 \%$ TCA) and incubated for $60 \mathrm{~min}$ at $4{ }^{\circ} \mathrm{C}$. The supernatant is discarded, and the plates are washed five times with tap water and air dried. Sulforhodamine B (SRB) solution (100 ml) at $0.4 \%(\mathrm{w} / \mathrm{v})$ in $1 \%$ acetic acid is added to each well, and plates are incubated for $10 \mathrm{~min}$ at room temperature. After staining, unbound dye is removed by washing five times with $1 \%$ acetic acid and the plates are air dried. Bound stain is subsequently solubilized with $10 \mu$ Mtrizma base, and the absorbance is read on an automated plate reader at a wavelength of $515 \mathrm{~nm}$. For suspension cells, the methodology is the same except that the assay is terminated by fixing settled cells at the bottom of the wells by gently adding $50 \mathrm{ml}$ of $80 \%$ TCA (final concentration, 16\% TCA).

\subsubsection{Data analysis}

Using the seven absorbance measurements [time zero, (Tz), control growth, $(\mathrm{C})$, and test growth in the presence of drug at the five concentration levels (Ti)], the percentage growth is calculated at each of the drug concentrations levels. Percentage growth inhibition is calculated as: $[(\mathrm{Ti}-\mathrm{Tz}) /(\mathrm{C}-\mathrm{Tz})] \times 100$ for concentrations for which $\mathrm{Ti}>/ 1 / 4 \mathrm{Tz}$ and $[(\mathrm{Ti}-\mathrm{Tz}) / \mathrm{Tz}] \mathrm{x} 100$ for concentrations for which $\mathrm{Ti}<\mathrm{Tz}$.

Three dose response parameters are calculated for each experimental agent. Growth inhibition of $50 \%\left(\mathrm{GI}_{50}\right)$ is calculated from $[(\mathrm{Ti}-\mathrm{Tz}) /(\mathrm{C}-\mathrm{Tz})] \times 100=50$, which is the drug concentration resulting in a $50 \%$ reduction in the net protein increase (as measured by SRB staining) in control cells during the drug incubation. The drug concentration resulting in total growth inhibition (TGI) is calculated from $\mathrm{Ti} 1 / 4 \mathrm{Tz}$. The $\mathrm{LC}_{50}$ (concentration of drug resulting in a 50\% reduction in the measured protein at the end of the drug treatment as compared to that at the beginning) indicating a net loss of 
cells following treatment is calculated from $[(\mathrm{Ti}-\mathrm{Tz}) / \mathrm{Tz}] \mathrm{x} 100=-50$. Values are calculated for each of these three parameters if the level of activity is reached; however, if the effect is not reached or is exceeded, the value for that parameter is expressed as greater or less than the maximum or minimum concentration tested (M.C. Alley, 1988,M.R. Grever, 1992).

\subsubsection{In vitro VEGFR tyrosine kinase activity at single dose of $10 \mu \mathrm{M}$ concentration.}

The VEGFR tyrosine kinase activity at single dose concentration of $10 \mu \mathrm{M}$ was carried out by BPS Bioscience (www.bpsbioscience.com). VEGFR (BPS\#40301) served as the enzyme source and Poly (Glu, Tyr) sodium salt, (4:1, Glu:Tyr) (Sigma\#P7244) served as the standardized substrate \& Kinase-Glo Plus Luminescence kinase assay kit (Promega\#V3772). The $\mathrm{IC}_{50}$ determination was carried out where quality control testing is routinely performed on each of the targets to insure compliance to acceptable standards. ${ }^{33} \mathrm{P}-\mathrm{ATP}$ was purchased from Perkin Elmer and ADP-Glo ${ }^{\mathrm{TM}}$ was purchased from Promega. All other materials were of standard laboratory grade.

\subsubsection{Assay protocols.}

The VEGFR tyrosine kinase activity was performed using Kinase-Glo Plus luminescence kinase assay kit (Promega). It measures kinase activity by quantitating the amount of ATP remaining in solution following a kinase reaction. The luminescent signal from the assay is correlated with the amount of ATP present and is inversely correlated with the amount of kinase activity. The compounds were diluted to $100 \mu \mathrm{M}$ in $10 \%$ DMSO and $5 \mathrm{ml}$ of the dilution was added to a $50 \mathrm{ml}$ reaction so that the final concentration of DMSO is $1 \%$ in all of reactions. All of the enzymatic reactions were conducted at $30{ }^{\circ} \mathrm{C}$ for $40 \mathrm{~min}$. The $50 \mu \mathrm{l}$ reaction mixture contains $40 \mu \mathrm{MTris}, \mathrm{pH} 7.4$, $10 \mu \mathrm{M} \mathrm{MgCl}_{2}, 0.1 \mathrm{mg} / \mathrm{ml} \mathrm{BSA}, 0.2 \mathrm{mg} / \mathrm{ml}$ Poly (Glu, Tyr) substrate, $10 \mu \mathrm{M}$ ATP and VEGFR. After the enzymatic reaction, $50 \mathrm{ml}$ of Kinase-GloPlus Luminescence kinase assay solution (Promega) was added to each reaction and incubate the plate for $5 \mathrm{~min}$ at room temperature. Luminescence signal was measured using a BioTek Synergy 2 microplate reader. The protein kinase assays used to determine $\mathrm{IC}_{50}$ value were performed using ADP-GloTM assay kit from Promega which measures the generation of ADP by the protein kinase. Generation of ADP by the protein kinase reaction leads to an increase in luminescence signal in the presence of ADP-GloTM assay kit. The assay was started by incubating the reaction mixture in a 96-well plate at $30{ }^{\circ} \mathrm{C}$ for $30 \mathrm{~min}$. After the 30 min incubation period, the assay was terminated by the addition of $25 \mathrm{ml}$ of ADP-GloTM Reagent (Promega). The 96 well plate was shaken and then incubated for $40 \mathrm{~min}$ at ambient temperature. $50 \mathrm{ml}$ of Kinase detection reagent was added, the 96well reaction plate was then read using the ADP-Glo Luminescences Protocol on a GloMax plate reader (Promega: Catalog \#E7031). Blank control was set up that included all the assay components except the addition of appropriate substrate (replace with equal volume of kinase assay buffer). The corrected activity for each protein kinase target was determined by removing the blank control value.

\subsubsection{Data analysis.}

VEGFR activity assays were performed in duplicate at each concentration. The luminescence data were analyzed using the computer software, Graphpad Prism. The difference between luminescence intensities in the absence of VEGFR $\left(\mathrm{Lu}_{\mathrm{t}}\right)$ and in the presence of VEGFR $\left(\mathrm{Lu}_{\mathrm{c}}\right)$ was defined as $100 \%$ activity $\left(\mathrm{Lu}_{\mathrm{t}}-\mathrm{Lu}_{\mathrm{c}}\right)$. Using luminescence 
signal $(\mathrm{Lu})$ in the presence of the compound, \% activity was calculated as: $\%$ Activity $=$ $\left\{\left(\mathrm{Lu}_{\mathrm{t}}-\mathrm{Lu}\right) /\left(\mathrm{Lu}_{\mathrm{t}}-\mathrm{Lu}_{\mathrm{c}}\right) \mathrm{X} 100 \%\right.$, where $\mathrm{Lu}=$ the luminescence intensity in the presence of the compound (all percent activities below zero were set to $0 \%$ ). \% Inhibition was calculated as: $\%$ inhibition $=100(\%)-\%$ activity. $\mathrm{IC}_{50}$ determination for inhibitor against VEGFR was estimated by generating a graph of $\log$ inhibitor vs normalized response with variable using the Prism software.

\subsection{Docking studies.}

All molecular modeling calculation and docking studies were carried out using Accelry's discovery studio 2.5 (Accelry's Discovery Studio 2.5, 2010). The X-ray crystal structure of the kinase domain of VEGFR in complex with its inhibitor (PDB code4ASD) was recovered RSCB protein data bank. Docking engine was validated; the co-crystallized ligand was extracted from the catalytic site and redocked to calculate the root mean square difference (RMSD)between the top docking pose and original crystallographic geometry. The amino acid residues were ionized using role based technique and the missing residues were completed. The protein structure was typed by CHARMM force field then it was minimized using 500 step of SMART minimizer of Discovery studio program (Minimizer adopt hybrid of steepest descent and conjugate gradient minimization algorithms). All the water molecules in the protein were deleted. Then minimization was done to the ligand before docking to give the lowest conformational energy for the ligand after preparation step. Docking was performed using CDocker protocol with the kinase active site.

\section{Acknowledgments}

The authors are grateful to The National Cancer Institute, Maryland, USA for performing anticancer activity.

\section{REFERENCES.}

ShulanZhang Y, YajingLiu,DongChen,WeihuanLan,Qiaol ngZhao, Chengcheng Dong,LinXia,PingGong. 2010. Synthesis and antitumor activities of novel 1,4-disubstituted phthalazine derivatives. Eur. J. Med. Chem. 45:3504-3510.

Ales Imramovský RJ, Karel Pauk, Eva Reznícková , Jan Dusek , irí Hanusek , Vladimír Krystof. 2013. Substituted 2-hydroxy-N-(arylalkyl)benzamides induce apoptosis in cancer cell lines. Eur. J. of Med. Chem. 68:253.

Nakhjiri M, Safavi M, Alipour E, Emami S, Atash AF, Jafari-Zavareh M, Ardestani SK, Khoshneviszadeh M, Foroumadi A, Shafiee A. 2012. Asymmetrical 2,6-bis(benzylidene)cyclohexanones: Synthesis, cytotoxic activity and QSAR study. Eur. J. Med. Chem. 50:113-123.

Hanahan D, Weinberg Robert A. 2011. Hallmarks of Cancer: The Next Generation. Cell 144:646-674.

Zhang J, Yang PL, Gray NS. 2009. Targeting cancer with small molecule kinase inhibitors. Nat Rev Cancer 9:28-39.

Qun Zhao HZ, Yong Li, Jun Liu, Xiaojie Hu, Liqiao Fan. 2010. Anti-tumor effects of CIK combined with oxaliplatin in human oxaliplatin-resistant gastric cancer cells in vivo and in vitro. J. Exp. Clin. Cancer Res. 29:118. 
Musumeci F, Radi M, Brullo C, Schenone S. 2012. Vascular Endothelial Growth Factor (VEGF) Receptors: Drugs and New Inhibitors. J. Med. Chem. 55:10797-10822.

Clarke JM, Hurwitz HI. 2013. Understanding and targeting resistance to antiangiogenic therapies. J. Gastrointest. Oncol. 4:253-263.

Potente MG, H.; Carmeliet, P. . 2011. Basic and therapeutic aspects of angiogenesis. Cell 146:873-887.

Francesca Musumeci MR, Chiara Brullo, and Silvia Schenone 2012. Vascular Endothelial Growth Factor (VEGF) Receptors: Drugs and New Inhibitors, J. Med. Chem. 55:10797-10822.

Holmes KR, O. L.; Thomas, A. M.; Cross, M. J. 2007. Vascular endothelial growth factor receptor-2: structure, function, intracellular signalling and therapeutic inhibition. Cell Signal. 19:2003-2012.

Koch ST, S.; Li, X.; Gualandi, L.; Claesson-Welsh, L. 2011. Signal transduction by vascular endothelial growth factor receptors. Biochem. J. 437:169-183.

Tomao F, Papa A, Rossi L, Zaccarelli E, Caruso D, Zoratto F, Benedetti Panici P, Tomao S. 2014. Angiogenesis and antiangiogenic agents in cervical cancer. Onco Targets Ther 7:2237-2248.

Zhang J, Yang PL, Gray NS. 2009. Targeting cancer with small molecule kinase inhibitors. Nat Rev Cancer 9:28-39.

Jabbour E, Cortes J, Ravandi F, O'Brien S, Kantarjian H. 2013. Targeted therapies in hematology and their impact on patient care: chronic and acute myeloid leukemia. Semin Hematol 50:271-283.

Scott EN, Meinhardt G, Jacques C, Laurent D, Thomas AL. 2007. Vatalanib: the clinical development of a tyrosine kinase inhibitor of angiogenesis in solid tumours. Expert Opin. Investig. Drugs 16:367-379.

Brian B. Hasinoff DP. 2010. The lack of target specificity of small molecule anticancer kinase inhibitors is correlated with their ability to damage myocytes in vitro. Toxicol. Appl. Pharm. 249:132-139.

Ott PA, Hamilton A, Min C, Safarzadeh-Amiri S, Goldberg L, Yoon J, Yee H, Buckley M, Christos PJ, Wright JJ, Polsky D, Osman I, Liebes L, Pavlick AC. 2010. A phase II trial of sorafenib in metastatic melanoma with tissue correlates. PLoS One 5:e15588.

Chuma M, Terashita K, Sakamoto N. 2014. New molecularly targeted therapies against advanced hepatocellular carcinoma: From molecular pathogenesis to clinical trials and future directions. Hepatol Res.

Yu B, Tang L-d, Li Y-l, Song S-h, Ji X-l, Lin M-s, Wu C-F. 2012. Design, synthesis and antitumor activity of 4-aminoquinazoline derivatives targeting VEGFR-2 tyrosine kinase. Bioorg. Med. Chem. Lett. 22:110-114.

Blanc J, Geney R, Menet C. 2013. Type II Kinase Inhibitors: An Opportunity in Cancer for Rational Design. Anticancer Agents Med Chem 13:731-747. 
L. Garuti MR, G. Bottegoni. 2009. Small Molecule Aurora Kinases Inhibitors. Curr. Med. Chem 16:1949-1963.

Shallal HM, Russu WA. 2011. Discovery, synthesis, and investigation of the antitumor activity of novel piperazinylpyrimidine derivatives. Eur. J. Med. Chem. 46:2043-2057.

Rice KD, Kim MH, Bussenius J, Anand NK, Blazey CM, Bowles OJ, CanneBannen L, Chan DSM, Chen B, Co EW, Costanzo S, DeFina SC, Dubenko L, Engst S, Franzini M, Huang P, Jammalamadaka V, Khoury RG, Klein RR, Laird AD, Le DT, Mac MB, Matthews DJ, Markby D, Miller N, Nuss JM, Parks JJ, Tsang TH, Tsuhako AL, Wang Y, Xu W. 2012. Pyrazolopyrimidines as dual Akt/p70S6K inhibitors. Bioorg. Med. Chem. Lett. 22:2693-2697.

Zhang S, Zhao Y, Liu Y, Chen D, Lan W, Zhao Q, Dong C, Xia L, Gong P. 2010. Synthesis and antitumor activities of novel 1,4-disubstituted phthalazine derivatives. Eur. J. Med. Chem. 45:3504-3510.

Pollard JR, Mortimore M. 2009. Discovery and Development of Aurora Kinase Inhibitors as Anticancer Agents. J. Med. Chem. 52:2629-2651.

Abouzid KM, Khalil N, Ahmed E. 2012. Synthesis and evaluation of anti-proliferative activity of 1,4-disubstituted phthalazines. Medicinal Chemistry Research 21:3288-3293.

D.M. Sammond KEN, J.M. Veal, R.T. Nolte, L. Wang, V.B. Knick, S.K. Rudolph, A.T. Truesdale, E.N. Nartey, J.A. Stafford, R. Kumar, M. Cheung. 2005. Bioorg. Med. Chem. Lett. 15:3519-3523.

Stout DM, Matier WL, Barcelon-Yang C, Reynolds RD, Brown BS. 1985. Synthesis and antiarrhythmic and parasympatholytic properties of substituted phenols. 3. Modifications to the linkage region (region 3). J Med Chem 28:295-298.

M.C. Alley DAS, A. Monks, M.L. Hursey, M.J. Czerwinski, D.L. Fine, B.J. Abbott, J.G. Mayo, R.H. Shoemaker, M.R. Boyd. 1988. Feasibility of drug screening with panels of human tumor cell lines using a microculture tetrazolium assay. Cancer Res. 48:589-601.

M.R. Grever SAS, B.A. Chabner,. 1992. The National Cancer Institute: cancer drug discovery and development program. Semin. Oncol 19:622-638.

Min Sun XW, Junqing Chen, Jin Cai, Meng Cao, Min Ji. 2010. Design, synthesis, and in vitro antitumor evaluation of novel diaryl ureas derivatives. Eur. J. Med. Chem. 45:2299-2306.

Accelry's Discovery Studio 2.5. 2010. San Diego: Accelrys Software Inc.,.

Smolyar NN, Yutilov YM. 2008. Cyclotransformation in the series of fused 5nitropyridin-2(1H)-ones. Russian Journal of Organic Chemistry 44:274-281.

Neumann G. 1893. Chemische Berichte; 26:708-709. 
"تصميم وتثييد مركبات مبنية على حلقة الفثلازين كمضادات محتملة للأورام السرطاتية".

للسادة الاكاترة

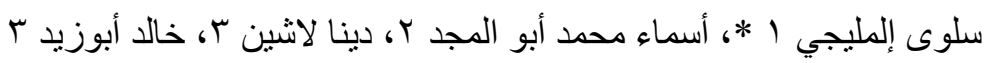

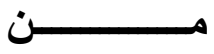

1 الصيدلية قسم الكيمياء العضوية، كلية الصيدلة، جامعة القاهرة، القاهرة، مصر

r ق بم كيمياء الصيدلة، كلية الصيدلة،

الجامعة الحديثة للتكنولوجيا و المعلومات، القاهرة، مصر

ب قسم الكيمياء الصيدلية، كلية الصيدلة، جامعة عين شمس، القاهرة، مصر الهر

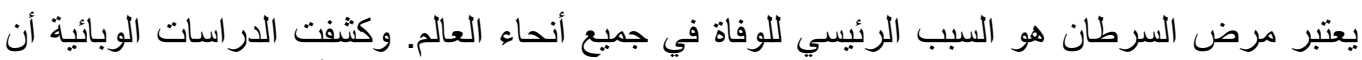

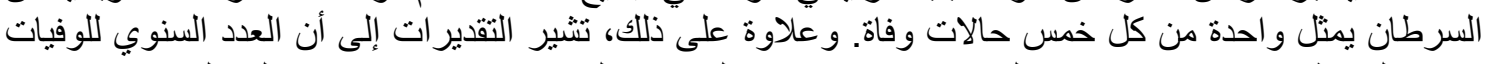

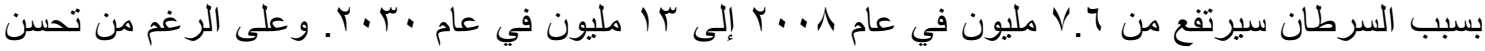

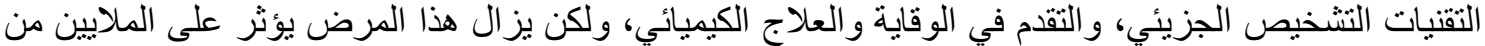

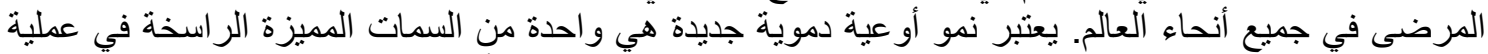

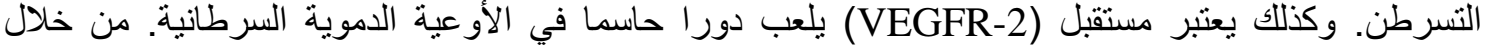
استهداف مستقبل (VEGFR)

يحتوى هذا البحث على مقدمة تشمل نبذة عن مرض السرطان ولئ وعن الدور الفعال الذى يلعبه انزيم

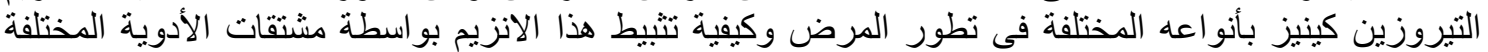

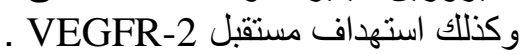

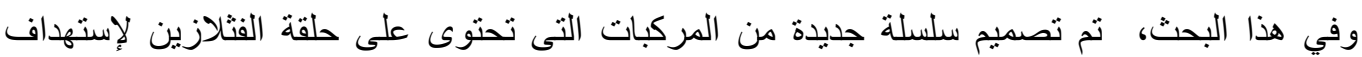

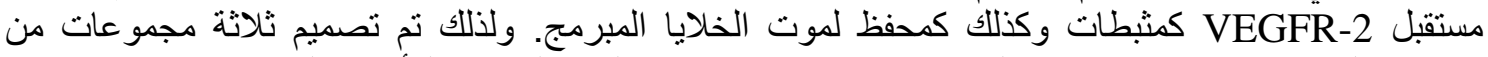

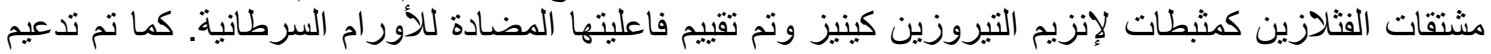

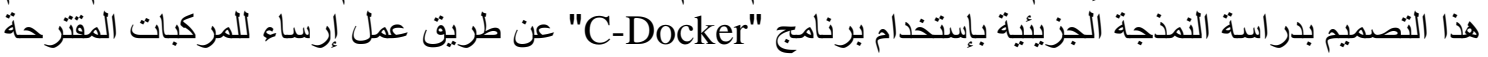

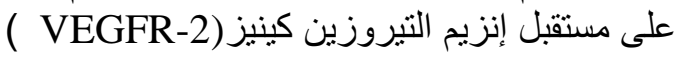

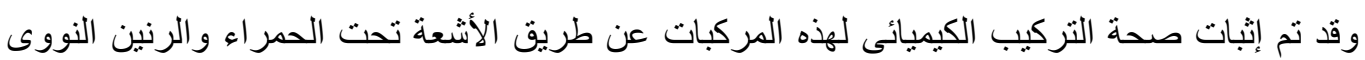

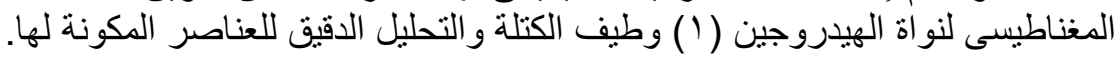

